\title{
Antarctic Snowmelt Detected by Diurnal Variations of AMSR-E Brightness Temperature
}

\author{
Lei Zheng ${ }^{1,2}$, Chunxia Zhou ${ }^{1,2, *}$, Ruixi Liu ${ }^{1,2}$ and Qizhen Sun ${ }^{3}$ \\ 1 Chinese Antarctic Center of Surveying and Mapping, Wuhan University, Wuhan 430079, China; \\ zhenglei0611@hotmail.com (L.Z.); liuruixi1113@163.com (R.L.) \\ 2 Key Laboratory of Polar Surveying and Mapping, National Administration of Surveying, Mapping and \\ Geoinformation, Wuhan 430079, China \\ 3 Key Laboratory of Research on Marine Hazards Forecasting, National Marine Environmental Forecasting \\ Center, Beijing 100081, China; sunqizhen@gmail.com \\ * Correspondence: zhoucx@whu.edu.cn
}

Received: 3 August 2018; Accepted: 28 August 2018; Published: 31 August 2018

\begin{abstract}
Antarctic surface snowmelt is sensitive to the polar climate. The ascending and descending passes of the Advanced Microwave Scanning Radiometer for Earth Observing System Sensor (AMSR-E) observed the Antarctic ice sheet in the afternoon (the warmest period) and at midnight (a cold period), enabling us to make full use of the diurnal amplitude variations (DAV) in brightness temperature $\left(\mathrm{T}_{\mathrm{b}}\right)$ to detect snowmelt. The DAV in vertically polarized $36.5 \mathrm{GHz} \mathrm{T}_{\mathrm{b}}$ (DAV36V) is extremely sensitive to liquid water and can reduce the effects of the structural changes in snowpacks during melt seasons. A set of controlled experiments based on the microwave emission model of layered snow (MEMLS) were conducted to study the changes of the vertically polarized $36.5 \mathrm{GHz} \mathrm{T}_{\mathrm{b}}$ $(\Delta 36 \mathrm{~V})$ during the transitions from dry to wet snow regimes. Results of the experiments suggest that $9 \mathrm{~K}$ can be used as a DAV36V threshold to recognize snowmelt. The analyses of snowmelt suggest that the Antarctic ice sheet began to melt in November and became almost completely frozen in late March of the following year. The total cumulative melt area from 2002 to 2011 was $2.44 \times 10^{6} \mathrm{~km}^{2}$, i.e., $17.58 \%$ of the Antarctic ice sheet. The annual cumulative melt area showed considerable fluctuations, with a significant (above $90 \%$ confidence level) drop of $5.24 \times 10^{4} \mathrm{~km}^{2} /$ year in the short term. Persistent snowmelt (i.e., melt that continues for at least three days) detected by AMSR-E and hourly air temperatures $\left(\mathrm{T}_{\text {air }}\right)$ were very consistent. Though melt seasons became longer in the western Antarctic Peninsula and the Shackleton Ice Shelf, Antarctica was subjected to considerable decreases in duration and melting days in stable melt areas, i.e., -0.64 and -0.81 days/year, respectively. Surface snowmelt in Antarctica decreased temporally and spatially from 2002 to 2011.
\end{abstract}

Keywords: Antarctica; snowmelt; AMSR-E; MEMLS

\section{Introduction}

The Antarctic ice shelves have undergone accelerated thinning and retreat in recent decades [1,2]. Iceberg calving and basal melt are the two dominant causes of the Antarctic surface mass loss [3,4]. Unlike in the Greenland ice sheet, surface snowmelt in the Antarctic ice sheet is relatively short-lived [5], and its contribution to the surface mass balance is negligible [6]. However, the Antarctic surface snowmelt can alter the surface radiative budget and indirectly affect the mass balance of ice sheets. Wet snow albedo is much lower than that of dry snow and absorbs more incoming solar radiation [7]. The refreezing of meltwater leads to the increase of snow grain size, which in turn decreases albedo and induces further melting [6,8]. During the melt seasons, meltwater can fill and magnify the ice crevasses on ice shelves; intensive snowmelt may even lead to the break-ups of ice shelves $[9,10]$. 
Therefore snowmelt is critical to the assessment of energy and mass balance of the ice sheet, and can act as an indicator of the stability of ice shelves [6,11-13].

Detection of the Antarctic surface snowmelt is of great importance for studying the polar climate, but the in situ data are very limited due to the remoteness and unfavorable environment. Spaceborne satellites can provide frequent and extensive observations for the monitoring of surface snowmelt in polar regions [6]. The microwave absorption and emissivity of snowpack increase greatly when liquid water emerges [14-17]. Consequently, microwave brightness temperatures $\left(T_{b}\right)$ vary greatly during the transitions from dry to wet snow regimes. Most spaceborne radiometers provide no less than two passes in a single day and can operate in all weather conditions [18]. Scanning Multi-Channel Microwave Radiometer (SMMR) and Special Sensor Microwave/Imager (SSM/I) have been used to study melting conditions on ice sheets by using single-channel [18-21] or multi-channel thresholding methods [22-28]. Melt signals can also be recognized based on wavelet transform-based or edge detection techniques by identifying the abrupt increases and decreases in $T_{b}$ values $[15,29,30]$. Some new methods have been proposed for threshold segmentation by using the generalized Gaussian model, which can achieve the automated monitoring of snowmelt $[17,31]$.

Single-channel methods determine snowmelt when $\mathrm{T}_{\mathrm{b}}$ exceeds the previous winter mean plus a certain value. After the refreezing of meltwater, strong volume scattering due to the increase of snow grain size can lead to low $\mathrm{T}_{\mathrm{b}}$ (even lower than the winter mean) in a dry snow regime [32]. Single-channel methods may fail to detect snowmelt when $\mathrm{T}_{\mathrm{b}}$ decreases during melt seasons because of the metamorphic snow structures. Freeze-thaw cycles may occur in a single day, especially for the melt and freeze-up onset when snowpack melts in the daytime and becomes frozen at night [33,34]. Ramage and Isacks $(2002,2003)$ utilized the diurnal amplitude variations (DAV, i.e., the difference of $\mathrm{T}_{\mathrm{b}}$ between ascending and descending passes) of SSM/I $37 \mathrm{GHz}$ vertically polarized $\mathrm{T}_{\mathrm{b}}$ to detect the timing of melt and refreeze onset $[35,36]$. The DAV method can reduce the effect of structural changes in melt detection, which was extended to the $19 \mathrm{GHz}$ channel and applied to Greenland [37]. The DAV method was also found to be more sensitive to wetness than the multi-channel method based on a cross-polarized gradient ratio (XPGR) between 19 and $37 \mathrm{GHz} \mathrm{T}_{\mathrm{b}}$. The XPGR method based on both channels requires higher values of snow wetness than the DAV method based on only the $37 \mathrm{GHz}$ channel [37].

Unlike SSM/I sensors, which varied in passing time due to orbit degradation, AMSR-E operated in a controlled orbit so that little acquisition time changes occurred during the operating period (http:/ / www.remss.com/support/crossing-times). Moreover, AMSR-E observed the Antarctic ice sheet in the afternoon (the warmest period) and at midnight (a cold period). Snowpacks are very likely to be melting in ascending observations and be frozen in descending observations, which enable us to make full use of the DAV method to detect snowmelt over the Antarctic ice sheet. This study aims at enhancing the understanding of Antarctic surface snowmelt in two aspects: (1) to minimize the effect of snow structural variations on melt detection by using the DAV method; and (2) to monitor the Antarctic surface snowmelt at stable and appropriate acquisition times with AMSR-E.

\section{Data Sets}

The AMSR-E radiometer onboard the NASA Earth Observing System (EOS) Aqua satellite is a modified version of the AMSR radiometer. The AMSR-E data $(6.9,10.7,18.7,23.8,36.5$, and $89.0 \mathrm{GHz}$ in both polarizations) used in this work were provided by the National Snow and Ice Data Center (NSIDC, www.nsidc.org), University of Colorado at Boulder. The source data were Level-2A swath brightness temperatures from the AMSR-E/Aqua L2A Global Swath Spatially-Resampled Brightness Temperatures (AE_L2A) data set [38]. NSIDC produced the data set by interpolating AMSR-E data to the output grids from swath space using an inverse distance squared method. These data were provided in south Lambert azimuthal projection at $25 \mathrm{~km}$ resolution. Vertically polarized $\mathrm{T}_{\mathrm{b}}$ at $36.5 \mathrm{GHz}$ of this data set was used to estimate the snowmelt onset (the first day of snowmelt), freeze-up (the last day of snowmelt), duration (the days between melt onset and freeze-up) and melting days in 
this study, the difference between duration and melting days represents the frozen days during melt season. The Antarctic coastlines, grounding lines, and $1 \mathrm{~km}$ Digital Elevation Model (DEM) used in this paper were also obtained from NSIDC [39-41].

To capture a continuous summer, a melting year starts on 1 July (the first day of the melting year (DOY)) and ends on 30 June in the next year. $\mathrm{T}_{\mathrm{b}}$ values of AMSR-E were extracted from the ascending and descending observations and merged into a database of sequential observations from 1 July 2002, to 30 June 2011. If any observation was missing, a value based on time-line interpolation was used. The Aqua satellite operated in controlled orbits and little change occurred (http:/ /www. remss.com/support/crossing-times). The equator crossing time (local time zone) of AMSR-E was 13:30 for ascending passes and 01:30 for descending passes. The acquisition time of the ascending and descending passes was recorded as minutes since midnight (0:00 UTC) of the date, which was converted to local time shown in Figure 1. Local acquisition time of the ascending and descending passes on 1 July 2002, as illustrated in Figure 1a,b, was concentrated in a narrow time span and showed little spatial variations. Figure $1 \mathrm{c}$ shows the local acquisition time histogram for the observations during 2008-2009 when no missing data were found. The chart illustrates that the local acquisition time of the ascending and descending passes varied from 13:32 to 16:54 (the warmest period) in the afternoon and from 21:51 to 01:51 (a cold period) at midnight. Melting snow in the daytime led to the sharp increase of the ascending $\mathrm{T}_{\mathrm{b}}$. When the snowpacks refroze in the night, the formation of an icy crust and the increase of snow grain size resulted in the strong scattering and low descending $\mathrm{T}_{\mathrm{b}}[32,35,36]$. This was a great opportunity for us to make full use of the DAV method to detect the Antarctic surface snowmelt.

(a)

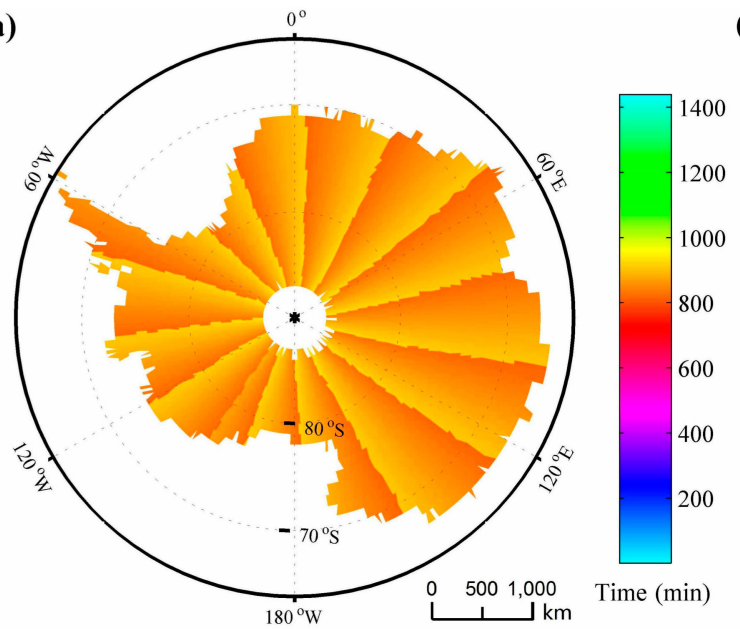

(b)

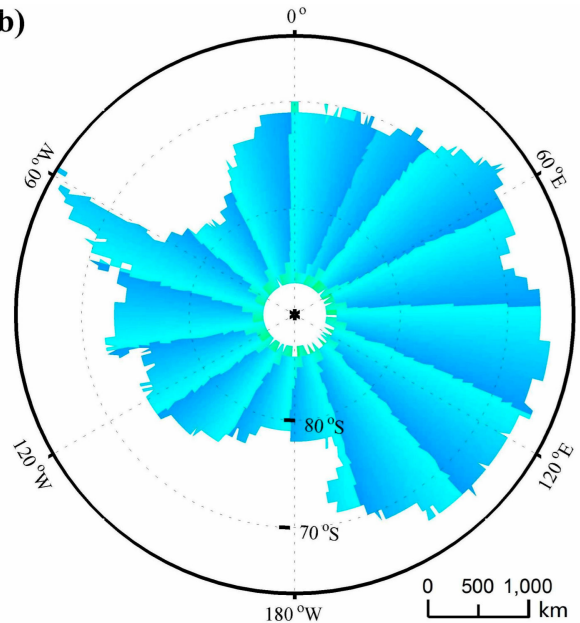

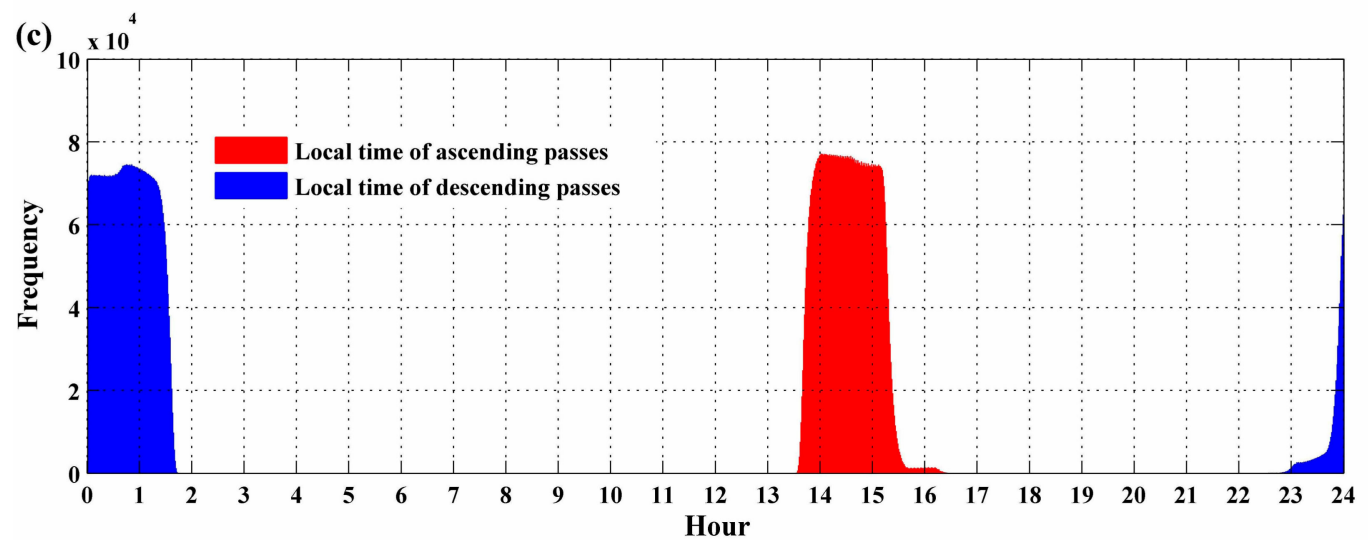

Figure 1. Local acquisition time of AMSR-E in the Antarctic. (a) Local acquisition time of the ascending pass on 1 July 2002, (b) local acquisition time of the descending pass on 1 July 2002, and (c) frequency of local acquisition time of AMSR-E between 2008 and 2009. 
Hourly meteorological observations were used to compare with the snowmelt detected by AMSR-E, which were obtained from the National Climatic Data Center of the National Oceanic and Atmospheric Administration (NCDC, www.ncdc.noaa.gov) and Chinese National Arctic and Antarctic Data Center (CN-NADC, www.chinare.org.cn). The hourly air temperatures $\left(\mathrm{T}_{\text {air }}\right)$ used in this study were observed by the automatic weather station (AWS) units. The installed AWS unit measures $\mathrm{T}_{\text {air }}$ at a nominal height of $3 \mathrm{~m}$ above the surface using resistance thermometers [42]. Sensors were placed in naturally ventilated shields that allowed air to circulate freely and reflect direct solar radiations. Keeping the sensors at a fixed height above the snow surface was the objective but difficult to achieve in practice. The measurement height of the sensors gradually decreased due to the snow accumulation.

\section{Methodology}

$\mathrm{T}_{\mathrm{b}}$ and DAV varied in different bands and polarizations in freeze-thaw cycles. The bands in different polarizations and passes are abbreviated in this paper, $\mathrm{A}$ and $\mathrm{D}$ indicate the ascending and descending orbit, $\mathrm{H}$ and $\mathrm{V}$ indicate the horizontal and vertical polarization. For example, A36V stands for vertically polarized $36.5 \mathrm{GHz}$ of the ascending pass, and DAV36V represents the difference between $\mathrm{A} 36 \mathrm{~V}$ and D36V. To select the optimal index for snowmelt detection, we compared these observations regarding their sensitivities to melt signals with simultaneous $\mathrm{T}_{\text {air }}$ around and above $0{ }^{\circ} \mathrm{C}$ (Section 3.1). The effect of snow liquid water on $\mathrm{T}_{\mathrm{b}}$ received by AMSR-E varied with different snow properties. Based on the Microwave Emission Model of Layered Snowpacks (MEMLS) developed by Wiesmann and Mätzler (1999) [43], a set of controlled experiments were designed to simulate the $T_{b}$ in melting snowpacks and determine the threshold of DAV36V used in this study (Section 3.2). The threshold was determined as the largest $T_{b}$ difference between the wet and dry snow regimes when $T_{b}$ presented the smallest variations with varying liquid water $(0-1 \%)$ in the experiment.

\subsection{Comparisons between $T_{b}$ and $D A V$}

We compared $\mathrm{T}_{\mathrm{b}}$ and DAV of each band at the Zhongshan Station $\left(69.37^{\circ} \mathrm{S}, 76.38^{\circ} \mathrm{E}\right)$ from 1 July 2010, to 30 June 2011 (Figure 2). Near-surface $T_{\text {air }}$ at the station (bottom panel in Figure 2) was used to interpret freeze-thaw cycles. Both $T_{b}$ and DAV significantly increased at snowmelt onset. $\mathrm{T}_{\mathrm{b}}$ dropped rapidly during the melt season due to the increasing of volume scattering [32]. By contrast, the DAV of each band showed a small magnitude in frozen seasons but great changes in snowmelt onset and freeze-up. Figure $2 \mathrm{a}, \mathrm{b}$ show the comparisons of the vertical and horizontal polarized observations, respectively. Observations in both polarizations exhibited similar trends in the same frequency [19], but the vertically polarized DAV showed relatively small values in cold seasons. Vertically polarized measurements were relatively insensitive to ice layers [44], which could reduce the interferences in the recognition of snowmelt. DAV18V was noisier than DAV36V [45], and DAV36Vs had distinct edges in the transitions of freeze-thaw cycles [46]. $\mathrm{T}_{\mathrm{b}}$ at 23.8 and $89.0 \mathrm{GHz}$ is strongly absorbed by water vapor in the atmosphere $[47,48]$. Of all the AMSR-E $\mathrm{T}_{\mathrm{b}} \mathrm{s}$ and DAVs, DAV36V was sensitive to snowmelt and also showed little variation in frozen seasons. DAV36V in combination with lower frequencies may be less sensitive to snow wetness than DAV36V alone [37]. Comparisons in other places show similar results. DAV36V has been successfully used in the detection of snowmelt at high latitudes and altitudes over the American continent [45,49-51]. In this work, DAV36V was applied to detect snowmelt in the Antarctic ice sheet:

$$
\mathrm{DAV} 36 \mathrm{~V}=\mathrm{A} 36 \mathrm{~V}-\mathrm{D} 36 \mathrm{~V}
$$

where $\mathrm{A} 36 \mathrm{~V}$ and $\mathrm{D} 36 \mathrm{~V}$ are the vertically polarized $36.5 \mathrm{GHz} \mathrm{T}_{\mathrm{b}}$ for the ascending and descending passes, respectively. 
(a)
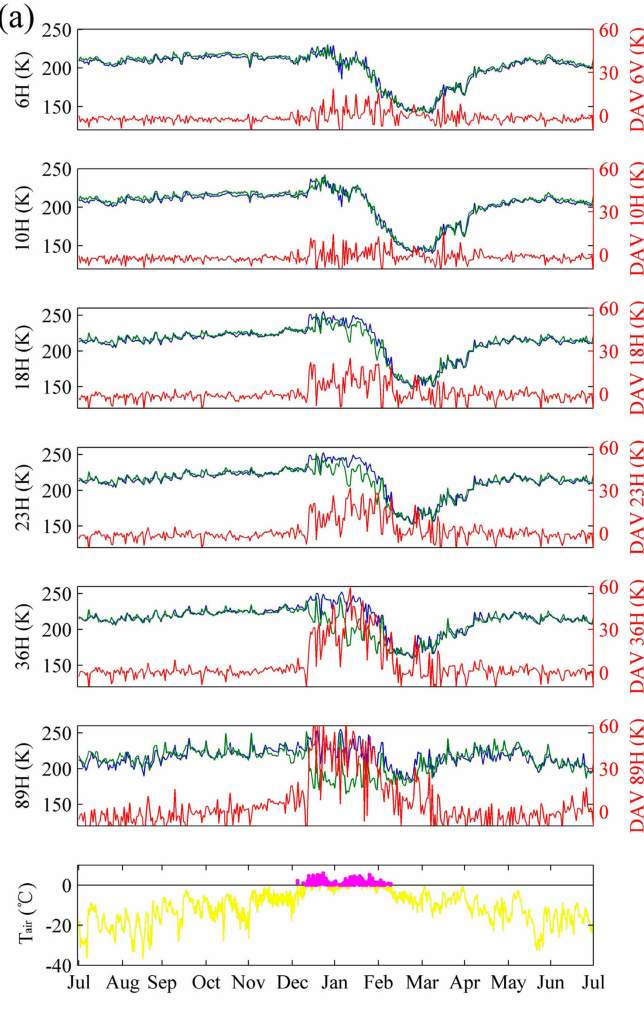

$-\mathrm{T}_{\mathrm{b}}$ in ascending pass $-\mathrm{T}_{\mathrm{b}}$ in ascending pass (b)
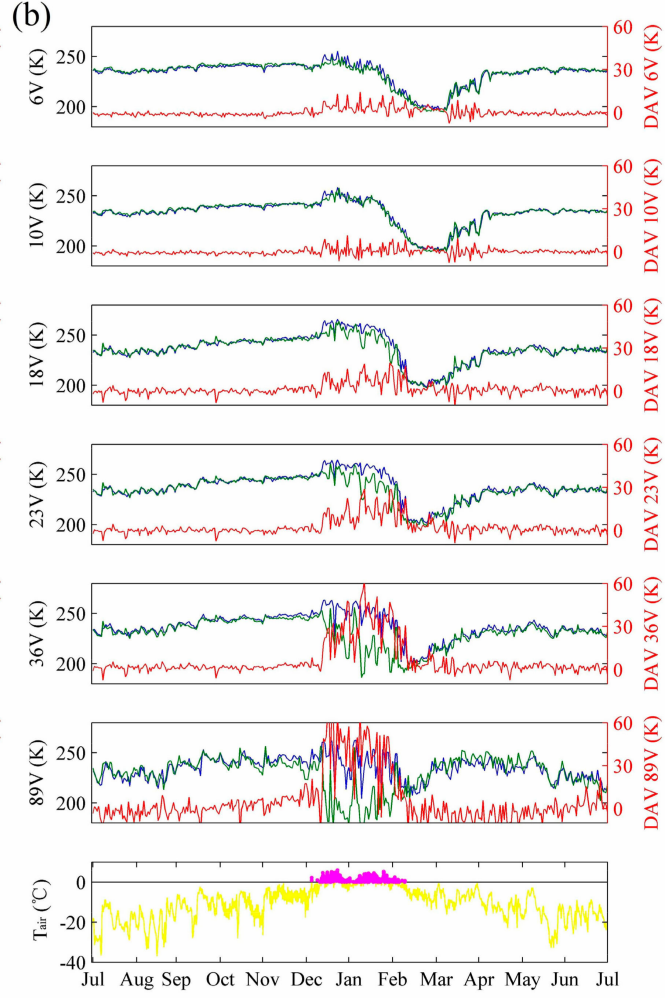

$\longrightarrow$ DAV T Tair $\quad \mathrm{T}_{\text {air }}=0^{\circ} \mathrm{C} \quad \cdots \cdots \mathrm{T}_{\text {air }}>0{ }^{\circ} \mathrm{C}$

Figure 2. The comparisons of ascending $\mathrm{T}_{\mathrm{b}}$ (blue lines), descending $\mathrm{T}_{\mathrm{b}}$ (green lines), and DAV (red lines) of each band at the Zhongshan Station from 1 July 2010, to 30 June 2011. (a,b) are the horizontal and vertical observations, respectively. $\mathrm{T}_{\text {air }}$ below and above $0{ }^{\circ} \mathrm{C}$ is indicated using a yellow line and magenta dots in the bottom panel; the black lines represent $\mathrm{T}_{\text {air }}$ equal to $0{ }^{\circ} \mathrm{C}$.

\subsection{Simulations with MEMLS}

To map the Antarctic snowmelt based on DAV36V, a reasonable threshold should be set to distinguish the melting days in freeze-thaw cycles. MEMLS based on the radiative transfer theory was used to simulate the behavior of vertically polarized $\mathrm{T}_{\mathrm{b}}$ at $36.5 \mathrm{GHz}$ regarding its response to the changes in the volumetric liquid water content. Snow cover in MEMLS was considered as a stack of horizontal planes. Absorption coefficient, scattering coefficient, effective permittivity, reflection, and refraction at the interfaces of the plane layers were described based on in situ measurements and physical models. Many parameters, including frequency, snow properties, incidence angle, snow-ground reflectivity, ground temperature, sky $\mathrm{T}_{\mathrm{b}}$, and the type of scattering coefficient, were required to simulate $\mathrm{T}_{\mathrm{b}}$ [43]. Mätzler and Wiesmann (1999) extended the model to coarse-grained snow by considering the growing and decaying of crusts during freeze-thaw cycles [52]. MEMLS-simulated $\mathrm{T}_{\mathrm{b}}$ shows a good matching with in situ observation [53]. MEMLS has been successfully used to determine the melt detection threshold based on SSM/I $19 \mathrm{GHz} \mathrm{T}_{\mathrm{b}}$ in horizontal polarization [54].

Snow depth (SD) and density ( $\rho$ ) vary greatly in Antarctica. Snow depth can be less than $20 \mathrm{~cm}$ at the tip of the Antarctic Peninsula and more than $100 \mathrm{~cm}$ inland [55]. Observed $\rho$ of freshly-fallen snow range from 10 to $257 \mathrm{~kg} / \mathrm{m}^{3}$ on the land surface [56]. Surface $\rho$ in East Antarctica vary from $310 \mathrm{~kg} / \mathrm{m}^{3}$ at Dome A to $460 \mathrm{~kg} / \mathrm{m}^{3}$ under the influence of katabatic winds in coastal regions [57]. Correlation length is a parameter that has significant impacts on the scattering and propagation of electromagnetic waves in snow packs, which is defined as the inverse of the derivative of autocorrelation function at zero displacement [43]. Exponential correlation length $\left(\mathrm{p}_{\mathrm{ec}}\right)$ is decided by the snow grain size (D) and $\rho$, and calculated based on an exponential function: $p_{\mathrm{ec}}=0.75\left(\rho / 917-\rho^{2} / 917\right) \mathrm{D}$ [58]. The reference 
range of $p_{\text {ec }}$ provided by MEMLS is from 0.05 for new snow to 0.3 for depth hoar [59]. Snowpacks are assumed to be homogeneous in the vertical direction. The incidence angle was set to $55^{\circ}$, the same as AMSR-E [60]. Snow-ground reflectivity at $36.5 \mathrm{GHz}$ was set to 0.083 and 0.045 in horizontal and vertical polarizations, respectively, according to a study of snow microwave signatures modeling of sea ice [61]. Sky background $\mathrm{T}_{\mathrm{b}}$ is $25 \mathrm{~K}$ at $36.5 \mathrm{GHz}$ [62]. We assumed that both the ground and snow temperatures were $273.15 \mathrm{~K}$ for slight snowmelt.

The melting snowpacks are characterized by a certain amount of liquid water. A set of controlled MEMLS simulations based on the snow properties discussed above were designed to simulate the changes of vertically polarized $\mathrm{T}_{\mathrm{b}}$ at $36.5 \mathrm{GHz}(\Delta 36 \mathrm{~V})$ in the transitions from dry to wet snow regimes. Simulations with different $\mathrm{SD}, \rho$, and $\mathrm{p}_{\mathrm{ec}}$ were examined. As shown in Figure 3 , we simulated $\Delta 36 \mathrm{~V}$ for the snowpacks with different $\operatorname{SD}(5,20,50$, and $200 \mathrm{~cm})$. Here, $\rho$ and pec were set to $400 \mathrm{~kg} / \mathrm{m}^{3}$ and 0.15 , respectively. Thicker snowpacks have more sensitive responses to the emergence of liquid water. With SD and $p_{\text {ec }}$ set to $50 \mathrm{~cm}$ and 0.15 , melting snowpacks with different $\rho(100,300,400$, and $500 \mathrm{~kg} / \mathrm{m}^{3}$ ) showed great variations in $\Delta 36 \mathrm{~V}$. Much larger changes in $\mathrm{T}_{\mathrm{b}}$ were found in looser snowpacks. Results with different $p_{\text {ec }}(0.05,0.1,0.15$, and 0.3$)$ are also presented where SD and $\rho$ were set to $50 \mathrm{~cm}$ and $400 \mathrm{~kg} / \mathrm{m}^{3}$, respectively. $\Delta 36 \mathrm{~V}$ of snowpacks with higher $\mathrm{p}_{\mathrm{ec}}$ were more sensitive to liquid water.

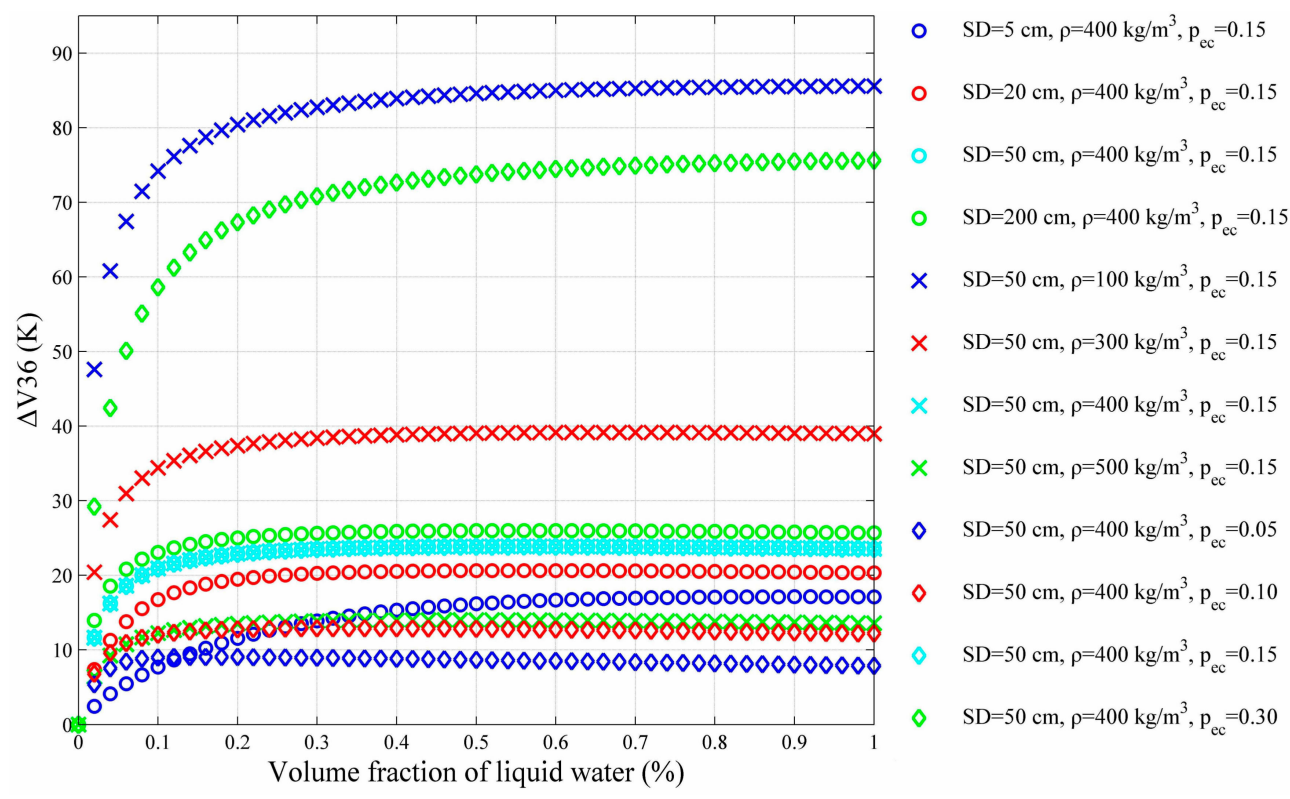

Figure 3. $\triangle 36 \mathrm{~V}$ of melting snowpacks simulated by MEMLS. Circles represent the simulations with different snow depths $(5,20,50$, and $200 \mathrm{~cm})$, where snow density and exponential correlation lengths were set to $400 \mathrm{~kg} / \mathrm{m}^{3}$ and 0.15 , respectively. Crosses represent the simulations with different snow densities $\left(100,300,400\right.$, and $\left.500 \mathrm{~kg} / \mathrm{m}^{3}\right)$, where snow depth and exponential correlation lengths were set to $50 \mathrm{~cm}$ and 0.15 , respectively. Diamonds represent the simulations with different exponential correlation lengths $(0.05,0.10,0.15$, and 0.30$)$, where snow depth and density were set to $50 \mathrm{~cm}$ and $400 \mathrm{~kg} / \mathrm{m}^{3}$, respectively.

The spectral behavior of the wet snow is dominated by the meltwater even when the liquid water content is $1 \%$ by volume [63]. Of all the simulations, $\Delta 36 \mathrm{~V}$ showed the largest increase $(86 \mathrm{~K})$ with a low snow density $\left(\mathrm{SD}=50 \mathrm{~cm}, \rho=100 \mathrm{~kg} / \mathrm{m}^{3}\right.$, and $\left.\mathrm{p}_{\mathrm{ec}}=0.15\right)$ when the volume fraction of liquid water varied from 0 to $1 \%$. $\Delta 36 \mathrm{~V}$ showed the smallest changes with a low $p_{\text {ec }}\left(\mathrm{SD}=50 \mathrm{~cm}, \rho=100 \mathrm{~kg} / \mathrm{m}^{3}\right.$, and $\left.\mathrm{p}_{\mathrm{ec}}=0.05\right) . \Delta 36 \mathrm{~V}$ could reach $9 \mathrm{~K}$ even under such snow conditions. Therefore, $9 \mathrm{~K}$ was used to identify melt signals in this study based on AMSR-E DAV36V. This threshold is very close to that $(10 \mathrm{~K})$ used in the detection of sea ice snowmelt based on SSM/I 37 GHz DAV [64]. 


\subsection{Threshold for DAV36V}

We set the DAV36V threshold as $9 \mathrm{~K}$ to detect the snowmelt according to the simulations. This value corresponded closely with the threshold Foster et al. (2011) used in the blended global snow product [46], however, much smaller than that (i.e., $18 \mathrm{~K}$ ) used to detect snowmelt over the Yukon River basin and the Southern Patagonia Icefield [49-51]. Melt detection on the Antarctic ice sheet is based on Equation (2):

$$
m(t)=\left\{\begin{array}{l}
1, D A V 36 V(t) \geq 9 K \\
0, D A V 36 V(t)<9 K
\end{array}\right.
$$

where $t$ is time and $m(t)$ represents snowmelt, with $m=1$ indicating melting and $m=0$ indicating frozen.

To test the adaptability of this method, we compared the $\mathrm{T}_{\mathrm{b}}, \mathrm{DAV} 36 \mathrm{~V}$ and daily maximum $\mathrm{T}_{\text {air }}$ of stations in Queen Maud Land (Novolazarevskaja Station, $70.77^{\circ} \mathrm{S}, 11.83^{\circ} \mathrm{E}$ ), Amery ice shelf (G3 Station, $70.90^{\circ} \mathrm{S}, 69.87^{\circ} \mathrm{W}$ ), the highest ice feature in Antarctica (Dome A Station, $80.38^{\circ} \mathrm{S}, 77.46^{\circ} \mathrm{E}$ ), and the Princess Elizabeth Land (Zhongshan Station). The daily maximum $\mathrm{T}_{\text {air }}$ was calculated by the hourly observation when at least four records were available. For the stations in Queen Maud Land and Amery ice shelf, A36V, D36V, and DAV36V showed rapid changes when the maximum $\mathrm{T}_{\text {air }}$ exceeded $0{ }^{\circ} \mathrm{C}$. In late melt seasons, some variations in $\mathrm{T}_{\mathrm{b}}$ (see the arrows in Figure $4 \mathrm{a}, \mathrm{b}$ ) corresponding to significantly positive $\mathrm{T}_{\text {air }}$ were too small to be detected by using a single-channel method (e.g., a threshold of $252 \mathrm{~K}$ used in Reference [49]). However, these melt signals were successfully recognized by DAV36V with a threshold of $9 \mathrm{~K}$. With an elevation of $4093 \mathrm{~m}$, Dome A is the highest ice feature in Antarctica. There was no melt or refreezing at Dome A [65], and the daily maximum $\mathrm{T}_{\text {air }}$ was far lower than $0{ }^{\circ} \mathrm{C}$. DAV36V showed little variation (less than $2 \mathrm{~K}$ ) throughout the year (Figure $4 \mathrm{c}$ ). The algorithm steadily detected the edges of freeze-thaw cycles at Zhongshan Station during 2002-2011 (Figure 4d). These comparisons suggested the threshold performs well in the detection of snowmelt compared with the $\mathrm{T}_{\text {air }}$ observation.

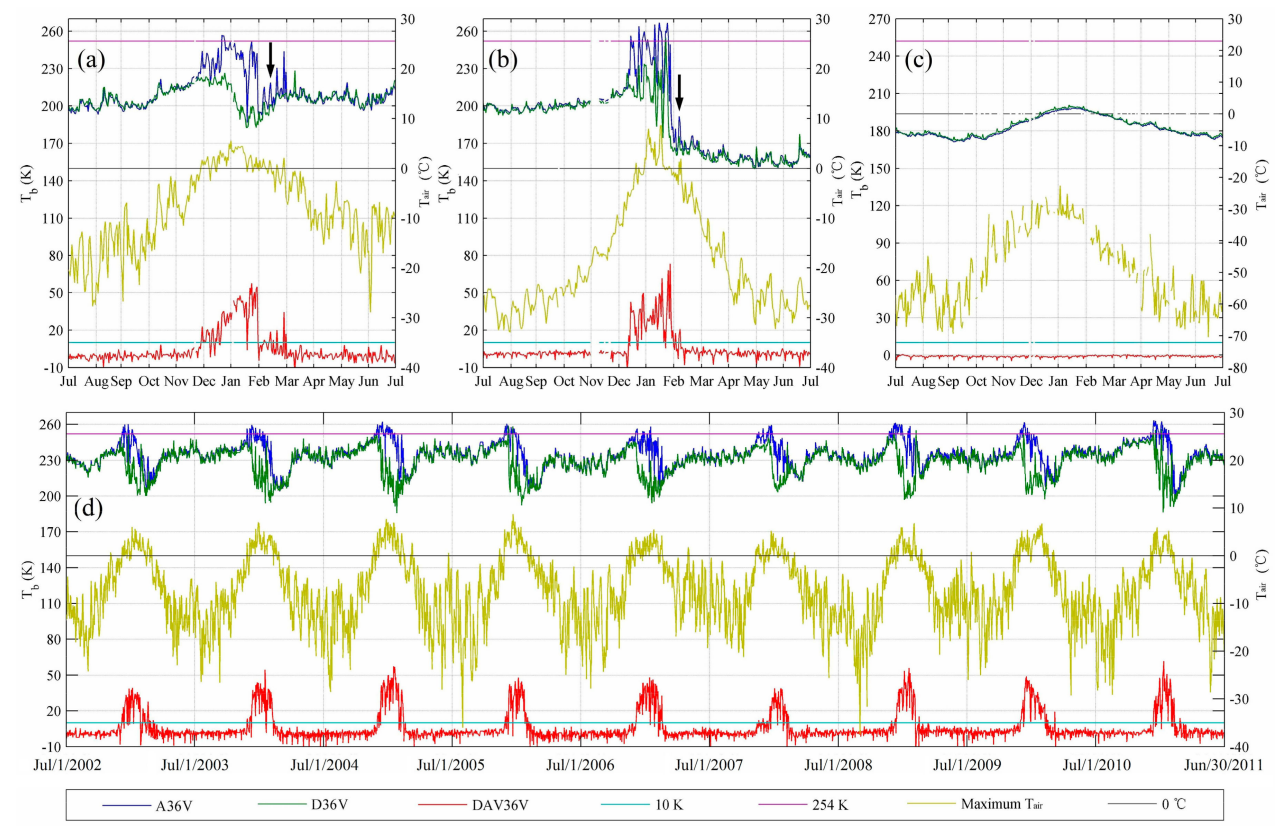

Figure 4. The comparison of A36V (blue lines), D36V (green lines), DAV36V (red lines), and daily maximum $\mathrm{T}_{\text {air }}$ (yellow lines) of (a) Novolazarevskaja Station (2003-2004), (b) G3 Stations (2004-2005) (c) Dome A Station (2007-2008), and (d) Zhongshan Station (2002-2011). The black line represents $\mathrm{T}_{\text {air }}$ equal to $0{ }^{\circ} \mathrm{C}$, magenta line represents the threshold ( $252 \mathrm{~K}$ ) of $36 \mathrm{~V}$ used in Reference [49], cyan line represents the threshold of $9 \mathrm{~K}$ used in the DAV36V method. The arrows point out the melt signals that were difficult for single-channel methods to detect. 


\subsection{Elimination of False Melt}

Though the method worked well in most of Antarctica, we found that DAV36V exceeded $9 \mathrm{~K}$ in very limited areas with high altitudes (even above $4000 \mathrm{~m}$ ), which mainly distributed near the rock outcrop. The specific heat capacity of rocks is much smaller than that of ice and water, thus may show higher ground temperature and DAV36V variations, which may be mistaken for melt signals sometimes. Moreover, spurious $\mathrm{Tb}$ variations may also result in false melt signals [32]. To eliminate these misidentifications of snowmelt, the standard deviation of DAV36V (SDD) and the difference of maximum DAV36V $(D M D)$ between warm and cold season were introduced in this study:

$$
\begin{aligned}
& S D D=\sqrt{\frac{\sum_{i=1}^{N}\left(\mathrm{DAV}_{3} 6 \mathrm{~V}_{i}-\overline{\mathrm{DAV} 36 \mathrm{~V}}\right)^{2}}{N}} \\
& D M D=\max \left(\mathrm{DAV} 6 \mathrm{~V}_{\text {warm }}\right)-\max \left(\mathrm{DAV} 6 \mathrm{~V}_{\text {cold }}\right)
\end{aligned}
$$

where $N$ is the number of days, and $i$ is the day, DAV36V $\mathrm{V}_{\text {warm }}$ denotes the DAV36V in the warm months (October to March), and DAV36V $\mathrm{V}_{\text {cold }}$ represents the relatively colder months (April to September).

$S D D$ and $D M D$ for the melting pixels are supposed to be higher than the maximum $S D D$ and $D M D$ for a dry snow zone. Tedesco et al. (2007) found the Antarctic snowmelt only occurred below $2000 \mathrm{~m}$ during 1987-2006 [66]. The highest temperature ever recorded in Antarctica is $17.5^{\circ} \mathrm{C}$ (http:/ / www.ogimet.com/), and the lapse rates for the western Antarctic Peninsula generally range from -5.7 to $-8.2{ }^{\circ} \mathrm{C} / \mathrm{km}$ [67], being smaller toward the inland because of the lower water vapor content. We assume that there is no snowmelt for the regions above $3500 \mathrm{~m}$. Therefore, SDD and DMD for the melt area should satisfy the following conditions:

$$
S D D>\max \left(S D D_{A 3500}\right) \text { and } D M D>\max \left(D M D_{A 3500}\right)
$$

where $\max \left(S D D_{A 3500}\right)$ and $\max \left(D M D_{A 3500}\right)$ represent the maximum $S D D$ and $D M D$ above $3500 \mathrm{~m}$ during 2002-2011, which were $2.53 \mathrm{~K}$ and $6.30 \mathrm{~K}$ respectively. The false melt signals at high altitudes are eliminated by this method.

\section{Spatial and Temporal Distribution of Snowmelt}

\subsection{Melt Area on the Antarctic Ice Sheet}

The daily melt area on the Antarctic ice sheet from 2002 to 2011 is shown in Figure 5a. Daily melt area showed considerable variations, and the largest melt area appeared in the austral summer of 2004-2005. Daily average melt area turned out to be approximately normally distributed (Figure 5b). The ice sheet began to melt in November and snowmelt expanded rapidly in December. After reaching a peak in mid-January, the melt area shrank quickly in February and became almost completely refrozen in late March. The largest annual average melt area was $1.408 \times 10^{5} \mathrm{~km}^{2}$ in 2004-2005, while the smallest was $8.99 \times 10^{4} \mathrm{~km}^{2}$ in 2007-2008. Annual average melt area showed sinusoidal fluctuations and a slight drop during this period (Figure $5 \mathrm{c}$ ). The trend $\left(-2.53 \times 10^{3} \mathrm{~km}^{2} /\right.$ year) of a least-square linear regression (also used in the following trend analysis) was not statistically significant. 
(a)
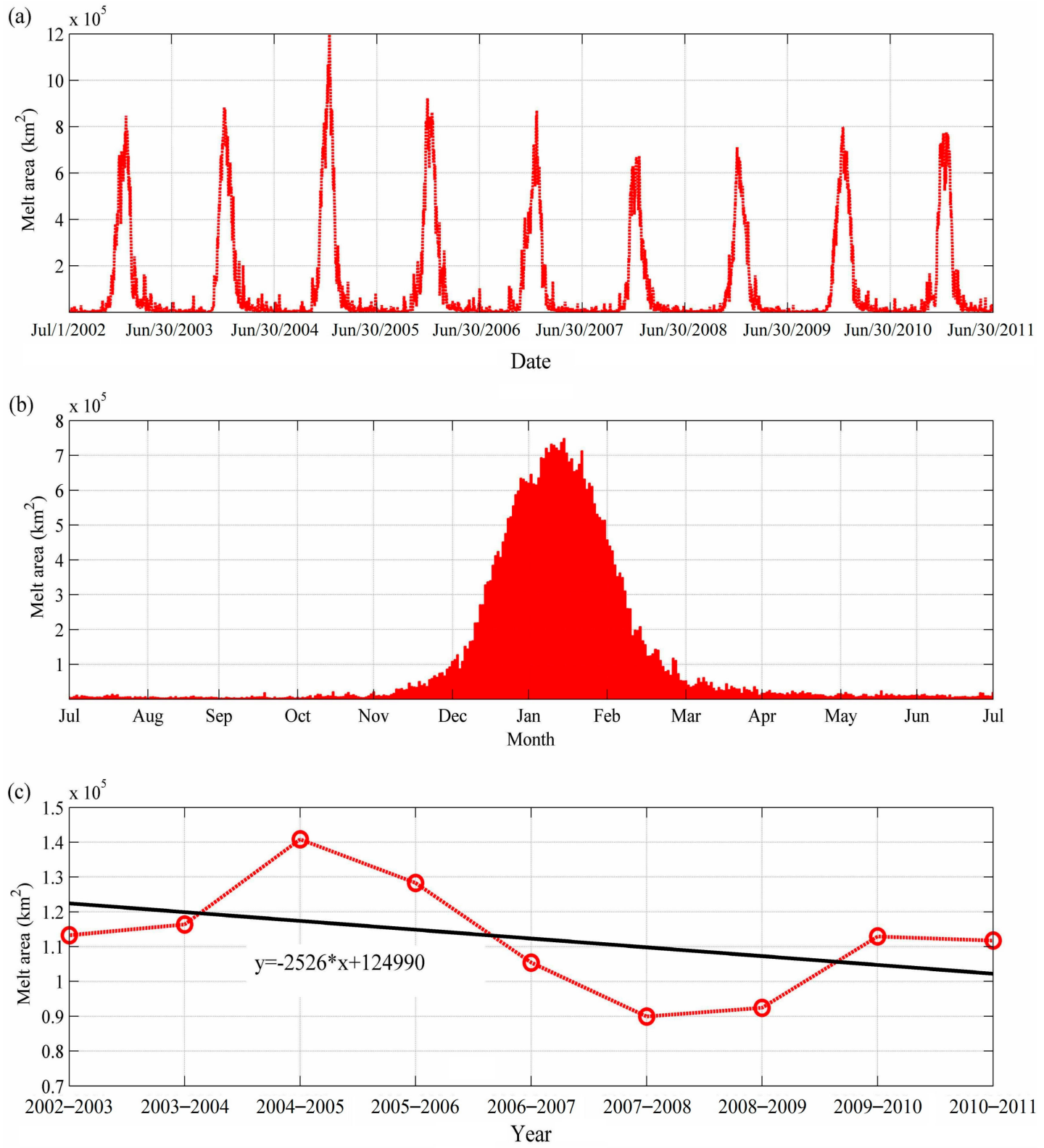

Figure 5. Statistics of melt area: (a) daily melt area, (b) daily average melt area, and (c) annual average melt area (red empty dots). The black line shows the average annual decrease rate of $2.53 \times 10^{3} \mathrm{~km}^{2} /$ year.

The total cumulative melt area (i.e., all places that experienced snowmelt in a certain period) from 2002 to 2011 was $2.44 \times 10^{6} \mathrm{~km}^{2}$, i.e., $17.58 \%$ of the Antarctic ice sheet (Figure 6a). During this period, the Antarctic Peninsula, and Ronne, Ross and Amery Ice Shelves, along with some other bigger ice shelves, experienced surface melt. Figure 6b shows the area that melted every year from 2002 to 2011 (referred to as stable melt area), including the Antarctic Peninsula, and Amery and Shackleton Ice Shelves, and some ice shelves in the Queen Maud Land, totalled an area of $6.95 \times 10^{5} \mathrm{~km}^{2}$. The comparison between Figure $6 \mathrm{a}, \mathrm{b}$ suggests that snowmelt at higher latitudes, such as the Ronne and Ross Ice Shelves, was variable. The cumulative melt area of each year showed considerable fluctuations, with a significant (above $90 \%$ confidence level) annual decrease of $5.24 \times 10^{4} \mathrm{~km}^{2}$ from 2002 to 2011 . The largest cumulative melt area was $1.90 \times 10^{6} \mathrm{~km}^{2}$ (2004-2005), while the smallest was $1.08 \times 10^{6} \mathrm{~km}^{2}$ (2008-2009) (Figure 6c). 

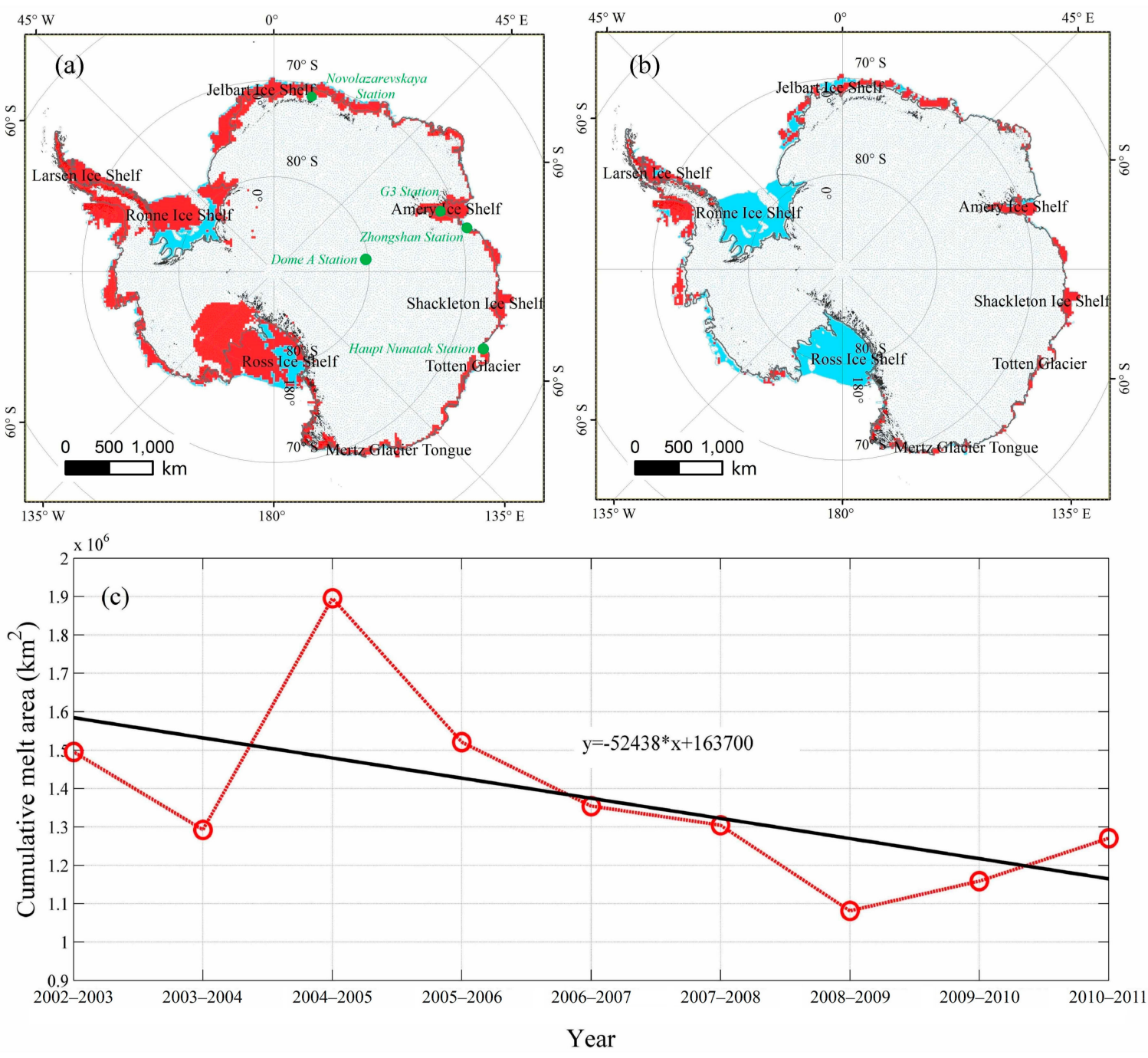

Figure 6. Cumulative melt area. Red areas in $(\mathbf{a}, \mathbf{b})$ are total cumulative melt area and stable melt area from 2002-2011, blue and brown areas are ice shelves and rock outcrops, and green points in (a) represent the locations of AWS stations. (c) Annual variations of cumulative melt area (red empty dots), with an annual decrease rate of $5.24 \times 10^{4} \mathrm{~km}^{2} /$ year (black line).

\subsection{Persistent Snowmelt on the Antarctic Ice Sheet}

\subsubsection{Validation of Persistent Snowmelt}

As mentioned above, snowmelt in Antarctica was variable, so the concept of persistent snowmelt (i.e., snowmelt that continues for at least three days) was applied to study the onset, freeze-up, and duration of Antarctic snowmelt [66]. Generally, it is difficult to quantify snow liquid water simply by air temperature. Other parameters, such as radiation fluxes, and sensible and latent heat, are also needed [34,68]. Nonetheless, the occurrence of surface melt corresponds to the spatial pattern of $\mathrm{T}_{\text {air }}$ [28]. Hence, in this study, $\mathrm{T}_{\text {air }}$ was used to evaluate the persistent snowmelt derived by AMSR-E. We assumed that persistent snowmelt also occurred when the maximum daily $\mathrm{T}_{\text {air }}$ was above $0{ }^{\circ} \mathrm{C}$ and lasted for at least three days. Although there are dozens of weather stations in Antarctica, many stations are located beside the sea, and melt signals are contaminated due to the sea water and are difficult to identify. Moreover, $\mathrm{T}_{\text {air }}$ has not been continuously recorded at many other stations (see the discontinuous $T_{\text {air }}$ in Figure $4 b, c$, the longest gap can be 4 days). We collected a long time series $T_{\text {air }}$ of three weather stations: the Zhongshan, Novolazarevskaya $\left(70.77^{\circ} \mathrm{S}, 11.83^{\circ} \mathrm{E}\right)$, and Haupt Nunatak 
$\left(66.58^{\circ} \mathrm{S}, 110.70^{\circ} \mathrm{E}\right)$ Station, where there were at least 12 records for each day. The persistent snowmelt derived from AMSR-E was in good agreement with $\mathrm{T}_{\text {air }}$, except for four points, as shown in Figure $7 \mathrm{a}$. This was because the AMSR-E data only provided two measurements per day, whereas there were many more records at the weather stations, which thus detected more persistent snowmelt. As shown in Figure $7 \mathrm{~b}, \mathrm{~T}_{\text {air }}$ at the Haupt Nunatak Station exceeded $0{ }^{\circ} \mathrm{C}$ and lasted for more than 3 days in the cold season in August 2007, while no snowmelt was detected by AMSR-E, which resulted in the mismatches of snowmelt onset and duration based on our algorithm. Similarly, at the Zhongshan Station (Figure 7c), mismatch C and D in Figure 7a can be explained by the sudden rise in temperature in April 2007 (Figure $7 \mathrm{c}$ ), which could be detected using the $\mathrm{T}_{\text {air }}$ data rather than AMSR-E. The correlation coefficient and root mean square error between the two measurements were 0.93 and 26.62 days. After removing the four mismatches in Figure 7a, the correlation coefficient and root mean square error become 0.99 and 12.07 days. The mean errors for persistent snowmelt onset, freeze-up, duration, and melting days were -4.76 days, 4.48 days, 9.05 days, and -0.33 days, respectively. Although the DAV36V method in this paper may overestimate snowmelt onset and underestimate freeze-up and duration compared to the snowmelt detected by $\mathrm{T}_{\mathrm{air}}$, it was a reliable and promising method for studying the variations of snowmelt.

(a)

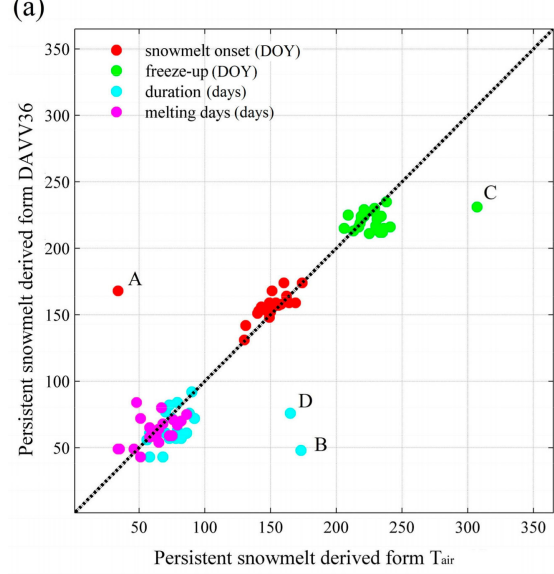

(b)

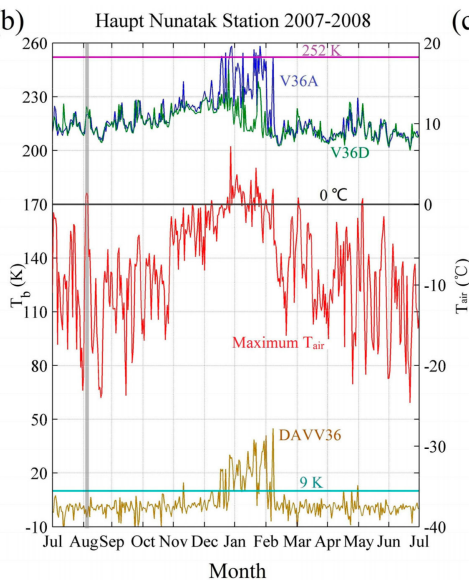

(c)

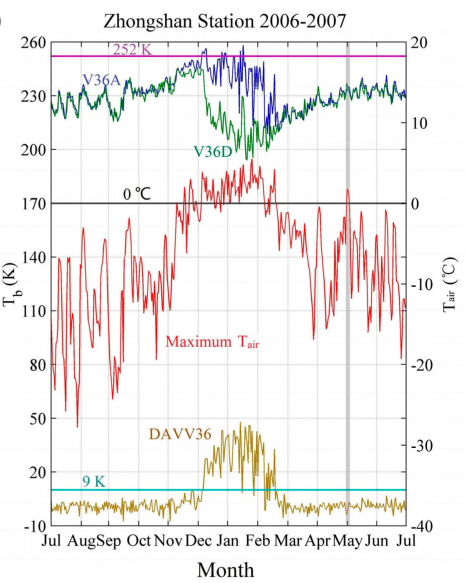

Figure 7. (a) Comparison of persistent snowmelt onset (red dots), freeze-up (green dots), duration (cyan dots), and melting days (magenta dots) derived from $\mathrm{T}_{\text {air }}$ and DAV36V. The dashed line represents $\mathrm{y}=\mathrm{x} ; \mathrm{A}, \mathrm{B}, \mathrm{C}$, and D are mismatches. (b) Source of mismatch A and B because of the sudden rise in $\mathrm{T}_{\text {air }}$ at the Haupt Nunatak Station in August 2007 (gray column). (c) Source of mismatch C and D because of the sudden rise in $\mathrm{T}_{\mathrm{air}}$ at the Zhongshan Station in April 2007 (gray column). The ascending $\mathrm{T}_{\mathrm{b}}$ (blue lines), descending $\mathrm{T}_{\mathrm{b}}$ (green lines), $\mathrm{DAV} 36 \mathrm{~V}$ (brown lines), and daily maximum $\mathrm{T}_{\text {air }}$ (red lines) are compared. The black lines represent $\mathrm{T}_{\text {air }}$ equal to $0^{\circ} \mathrm{C}$, magenta lines mean the threshold of $36 \mathrm{~V}$ used in Reference [49], and cyan lines represent DAV36V $=9 \mathrm{~K}$.

\subsubsection{Persistent Snowmelt over Antarctica}

We produced persistent snowmelt onset, freeze-up, duration, and melting days for 2002-2011 (Figure 8). Duration and melting days decreased from the coastlines toward the inland, from lower latitudes to higher latitudes, and from lower altitudes to higher altitudes; in the same direction, persistent snowmelt onset came later and freeze-up came earlier. The earliest snowmelt occurred on the Antarctic Peninsula and lasted for several months. Melt occurred late on the Ross and Ronne Ice Shelves and lasted for only several days (less than 10 days). Snowmelt in these places was variable. Many regions on the Ross Ice Shelf were subjected to melting during 2002-2006 but were almost completely frozen over the next few years. On the contrary, persistent snowmelt emerged on the Amery Ice Shelf every year due to the lower latitudes. Lower latitudes also explain why melt seasons in East Antarctica began earlier and ended later compared to those in West Antarctica, with the exception of the Antarctic Peninsula. 
(a)
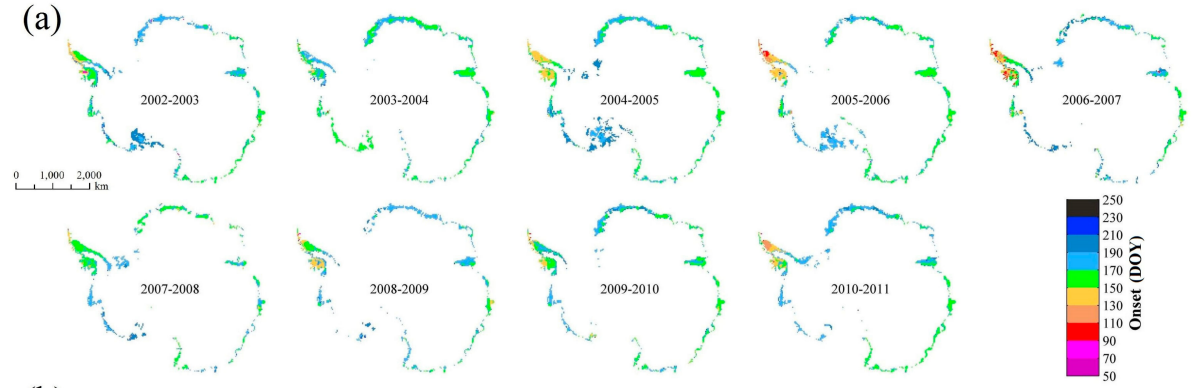

(b)
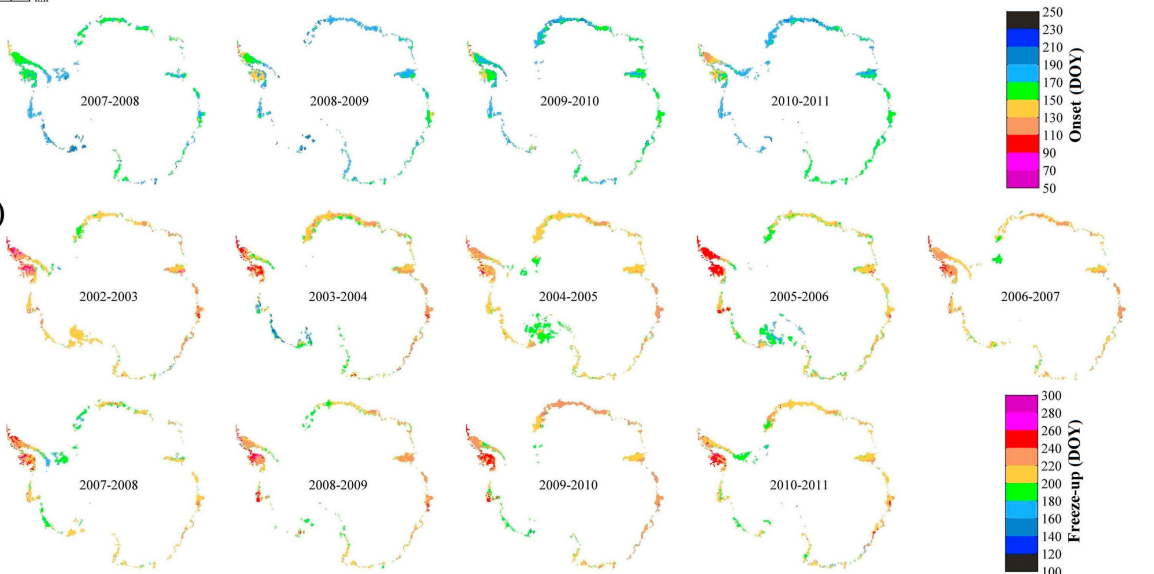

(c)
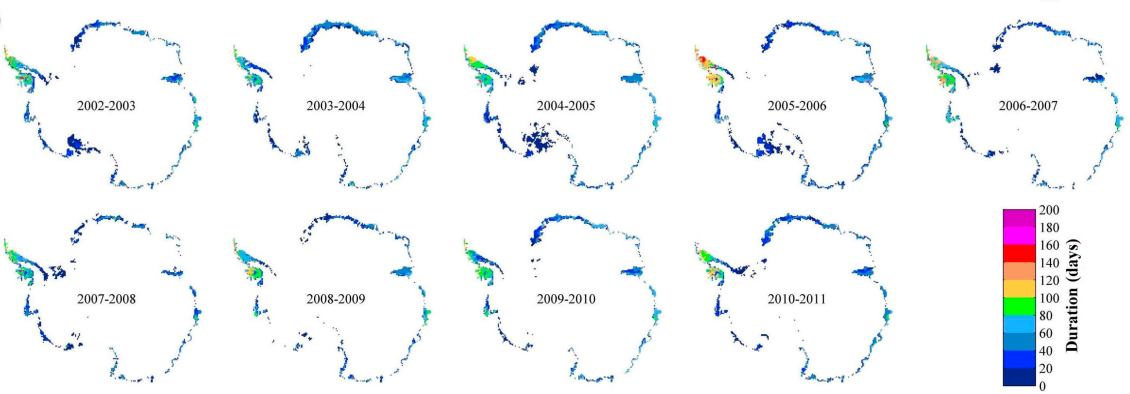

(d)
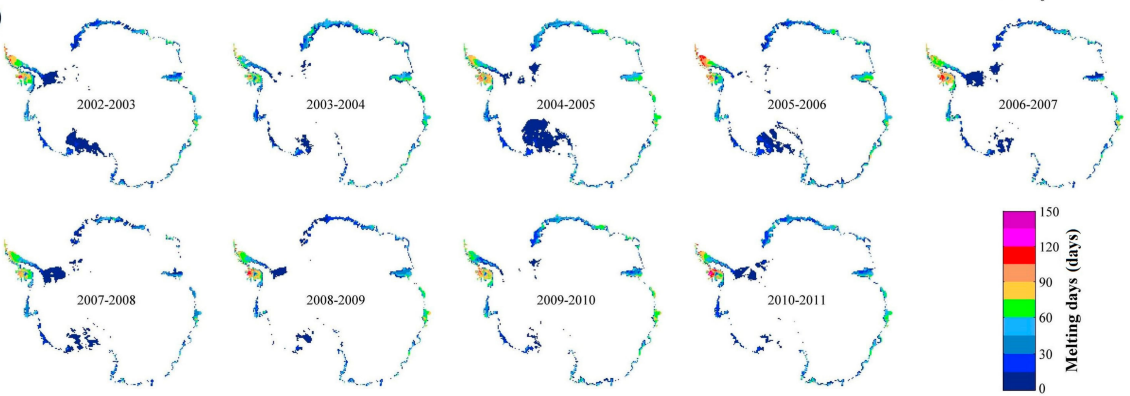

Figure 8. Maps showing the persistent snowmelt (a) onset, (b) freeze-up, (c) duration, and (d) melting days from 2002 to 2011.

We also analyzed the spatial and temporal distribution of the annual mean persistent snowmelt for the stable melt area (Figure 9). Generally, persistent snowmelt started in mid-October on the Antarctic Peninsula and extended gradually toward other larger ice shelves until late January (Figure 9a). Intensive snowmelt was found in the grounding zone of the Larsen C Ice Shelf. Persistent snowmelt onset reached the peak in early January (Figure 9b). The average of persistent snowmelt onset was DOY 161. The ice shelves in Queen Maud Land became refrozen in early January, while most of the Antarctic Peninsula was still experiencing melting until February (Figure 9c). The duration of persistent snowmelt on the Antarctic Peninsula was more than two months, while melt seasons rarely lasted for more than one month in other places (Figure 9e). The annual averages of persistent freeze-up and duration were DOY 212 and 52 days, respectively (Figure 9d,f). Melting days showed a spatial distribution similar to the persistent snowmelt duration (Figure 9g). The frequency of melting days showed two peaks: one was approximately 5 days and the other was approximately 47 days (Figure $9 \mathrm{~h}$ ), indicating ephemeral and continuous snowmelt respectively. 


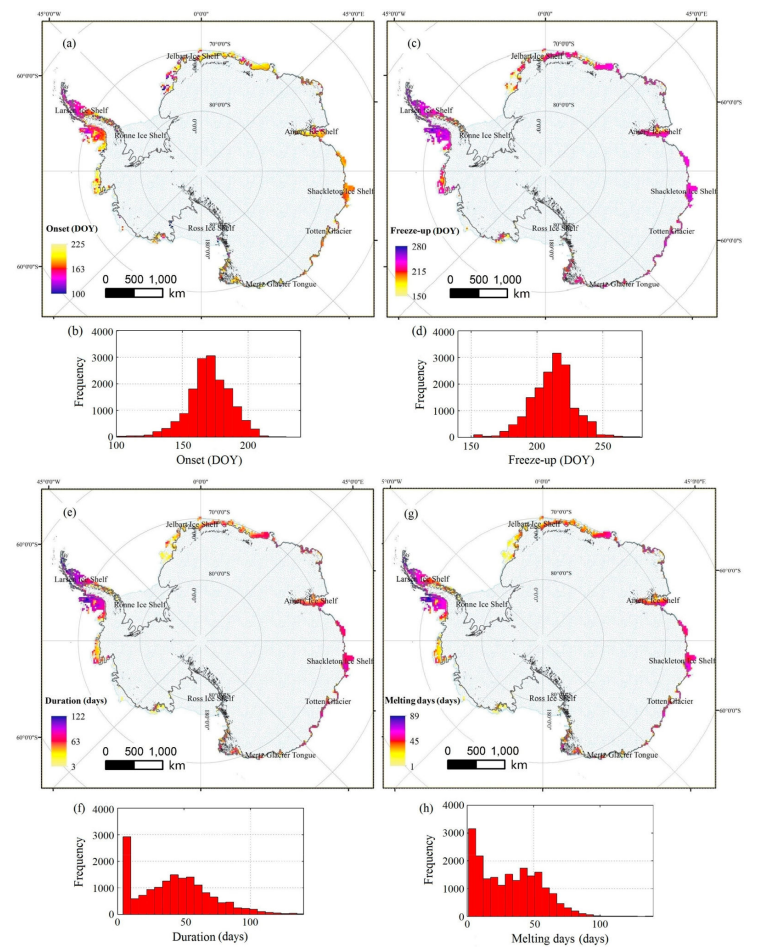

Figure 9. Statistics of persistent snowmelt onset, freeze-up, duration, and melting days for stable melt area. (a,c,e,g) show the annual average of persistent snowmelt onset, freeze-up, duration, and melting days, while $(\mathbf{b}, \mathbf{d}, \mathbf{f}, \mathbf{h})$ show the histograms of persistent snowmelt onset, freeze-up, duration, and melting days.

Most of the Antarctic presented a trend toward shorter melt duration and less melting days, with a corresponding earlier freeze-up. Areas with positive trends in duration in the Antarctic Peninsula generally had earlier melt onset and later freeze-up. The Antarctic persistent snowmelt showed an annual increase of 0.43 days for onset and an annual decrease of 0.21 days for freeze-up from 2002 to 2011 (Figure 10a,b). Though melt seasons became longer in the western Antarctic Peninsula and the Shackleton Ice Shelf, Antarctica experienced overall decreases in duration and melting days in the short term, 0.64 and 0.81 days/year, respectively (Figure 10c,d). Lack of statistical significance in these trends suggest large inter-annual variability in the Antarctic snowmelt timing.

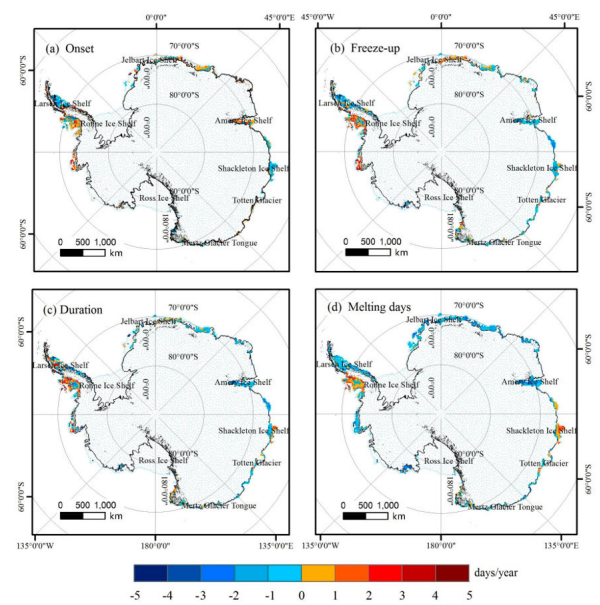

Figure 10. Trends in persistent snowmelt (a) onset, (b) freeze-up, (c) duration, and (d) melting days for stable melt area. 


\section{Discussion}

\subsection{Uncertainties and Limitations}

$36 \mathrm{~V}$ increased for at least $9 \mathrm{~K}$ in MEMLS simulations when experiencing slight snowmelt (0-1\%). This value is very close to that $(10 \mathrm{~K})$ used in snowmelt detection on the Antarctic sea ice based on SSM/I DAV at $37 \mathrm{GHz}$ in vertical polarization [64,69]. MEMLS has been successfully used to determine the threshold for melt detection on the Antarctic based on SSM/I T $\mathrm{b}_{\mathrm{b}}$ at $19.35 \mathrm{GHz}$ [54]. The uncertainties of the simulations come from two aspects. One comes from the MEMLS, such as the insensitivity to polarization, the assumptions of smooth interfaces between layers, and the limited range of correlation lengths [43]. The other aspect was the assumptions about snow properties we made. Snowpacks were regarded as homogeneous in the simulations. Snow temperature always shows considerable variations at different depths. Overall increases of the snow density and grain size with depth were found on the ice sheet due to snow compaction and metamorphism [70,71]. The Antarctic is not totally snow-covered, rock outcrops, blue ice, and melting ponds are also widely distributed [72,73]. Snow profiles and the underling surface in the Antarctic are much more complex than what we set in the simulations. The snow-ground reflectivity used in the simulations was quoted from a work on sea ice. Ice emissivity at $36.5 \mathrm{GHz}$ in vertical polarization can be as low as 0.7 (i.e., reflectivity can be up to 0.3 when neglecting transmissivity) [74]. Nevertheless, the threshold for DAV36V determined by the simulations shows little variation (less than $0.4 \mathrm{~K}$ ) with snow /ice interface reflectivity varying from 0 to 0.3 . The AMSR-E incidence angle may deviate by about $\pm 0.5^{\circ}$ from the nominal angle $\left(55^{\circ}\right)$ due to the oblateness of the Earth [75]. The little incidence angle variation also results in limited variations (less than $0.2 \mathrm{~K}$ ) on the threshold, which is negligible in melt detection.

Though many uncertainties exist, the threshold of $9 \mathrm{~K}$ performed well in melt detection when compared with $\mathrm{T}_{\text {air }}$. Slightly more melting days (0.33 days) were recognized by $\mathrm{T}_{\text {air }}$. $\mathrm{T}_{\text {air }}$ with more than 12 daily observations had more opportunities to detect snowmelt than AMSR-E with only two passes. AWS observed $\mathrm{T}_{\mathrm{air}}$ at single points, while AMSR-E received $36.5 \mathrm{~T}_{\mathrm{b}}$ from an instantaneous field of $8.2 \times 14.4 \mathrm{~km}$, which was interpolated at a spatial resolution of $25 \times 25 \mathrm{~km}$ in the product. The inconsistent spatial scale of the two measurement systems was another important reason for the discrepancies in melt detection. The ideal threshold for DAV36V may vary in different regions due to the changing meteorological conditions and snow characteristics. Wavelet algorithms have been used to automatically identify melt signals based on single-channel $\mathrm{T}_{\mathrm{b}}$ [30], as well as backscatter coefficient derived from a scatterometer [76]. These methods are independent of snow properties, and were found to be more sensitive to melt signals than fixed-threshold methods [76]. An automatic melt detection method is already in progress to study the Antarctic melting conditions based on AMSR-E DAV at different frequencies. The DAV36V method may fail to recognize heavy snowmelt when snow is soaked with water and even melts at midnight. Moreover, when meltwater does not refreeze or percolates below the microwave penetration depth in the warm nights, the DAV method may fail to work as well. Snowmelt in the Antarctic is short-lived. The freeze/thaw state can change in a very short time. Though AMSR-E observed Antarctica at appropriate times for snowmelt detection, it is still possible for only two daily measurements to miss the time when snowmelt occurs without concurrent satellite observation. AMSR-E may underestimate the snowmelt on the Antarctic ice sheet due to the limited satellite observations.

\subsection{Comparisons and Implications}

Considerable spatial and temporal melt variations were found in the Antarctic ice sheet based on AMSR-E, which were consistent with some earlier studies. The most extensive snowmelt derived by AMSR-E in 2004-2005 was also observed by QuikSCAT [77]. The Antarctic ice sheet began to melt in November and became almost completely refrozen in late March. Most surface snowmelt in Antarctica occurred from December to February, and peaked in early January. The seasonal evolution of the melt area detected in this study agreed well with that derived by SMMR and SSM/I since 
$1978[15,21]$. The maximum daily mean melt area during 2002-2011 derived by AMSR-E was about $1.5 \times 10^{5} \mathrm{~km}^{2}$ smaller than that mapped by SMMR and SSM/I during 1978-2004 [15], possibly due to the negative trend in Antarctic melt area. The Antarctic cumulative melt area mapped by AMSR-E showed considerable variations, especially for the ice shelves at high latitudes. However, the cumulative melt area showed a decreasing trend $\left(5.24 \times 10^{4} \mathrm{~km}^{2} /\right.$ year $)$ above the $90 \%$ confidence level during 2002-2011.

Melt seasons in the Antarctic Peninsula occurred the earliest and lasted for several months. Over the past several decades, the Antarctic Peninsula has witnessed rapid warming, leading to extensive surface snowmelt, as well as the disintegration of ice shelves [2,9]. On the Larsen C Ice Shelf, the most intensive snowmelt was found in the grounding zone. The dry föhn winds flow across the Antarctic Peninsula, flush away the cool air and warm the snow surface, leading to the extremely high melt rates in the grounding zone [12,78]. On the contrary, snowmelt at high latitudes showed significant annual variations, especially in the Ross and Ronne Ice Shelves where snowmelt only lasted for a few days (see Figures 6 and 8). The positive albedo feedback of wet snow in these regions should be fully considered in the prediction of future melting and meteorological conditions in Antarctica. The Antarctic melt area has been decreasing during 1987-2006 based on SSM/I observations [66]. The decreasing trend lasted until 2011 according to the melt area mapped by AMSR-E in this study. The Antarctic presented reductions in melt duration ( -0.64 days/year) and melting days ( -0.81 days/year) in the short term. The negative trend in the Antarctic surface snowmelt may have resulted from the positive trend of the Southern Hemisphere Annular Mode (SAM) $[79,80]$. However, the increase in melt duration and melting days of the western Antarctic Peninsula may be explained by the increasing temperature. This warming trend was found to be associated with increasing pressure in the South Atlantic [81]. Plenty of studies have highlighted a strong correlation between the Antarctic snowmelt with meteorological conditions (e.g., [15,76,80]), suggesting that snowmelt can serve as a diagnostic indicator for the polar climate.

Though both the Antarctic melt area and melt duration decreased from 2002 to 2011, a negative mass balance of the Antarctic ice sheet has been reported by some recent studies, which was contributed by the enhanced basal melt and iceberg calving $[1,3,4]$. Unlike the Greenland ice sheet where a large proportion of the annual mass loss is contributed by meltwater run-off [82], meltwater in the Antarctic ice sheet refreezes quickly in the snowpacks, and its contribution to the surface mass balance is limited and negligible $[1,6]$. Nevertheless, surface snowmelt can affect the surface mass balance indirectly, such as triggering ice-shelf collapses [10] and hence accelerating the ice flow [83].

\section{Conclusions}

The ascending and descending passes of AMSR-E provided passive microwave remote sensing data over the Antarctic ice sheet in the afternoon and at midnight, respectively. DAV can be used to explore the snowmelt of the Antarctic ice sheet by taking full advantage of the optimum local acquisition time. After comprehensive comparisons of $\mathrm{T}_{\mathrm{b}}$ and DAV of each band in both horizontal and vertical polarizations, DAV36V were selected to investigate the presence of liquid water over Antarctica. The DAV36V method performed well when compared with in situ $\mathrm{T}_{\text {air }}$ observations. The Antarctic snowmelt onset, freeze-up, duration, and melting days were mapped based on this method.

Daily average melt area peaked in early January and turned out to be approximately normally distributed in melt seasons. Annual average melt area showed sinusoidal fluctuations and a slight drop during this period. The largest and smallest annual average melt area were $1.408 \times 10^{5} \mathrm{~km}^{2}$ in 2004-2005 and $8.99 \times 10^{4} \mathrm{~km}^{2}$ in 2007-2008. The total cumulative melt area from 2002 to 2011 was $2.44 \times 10^{6} \mathrm{~km}^{2}$, i.e., $17.58 \%$ of the Antarctica ice sheet. Annual cumulative melt area showed considerable fluctuations, with a significant negative trend $\left(-5.24 \times 10^{4} \mathrm{~km}^{2} /\right.$ year $)$ above the 90\% confidence level. Persistent snowmelt detected by AMSR-E and $\mathrm{T}_{\text {air }}$ were consistent with a correlation coefficient of 0.93. Melt seasons could last for several months on the Antarctic Peninsula, while snowmelt was variable and short-lived on the Ross and Ronne Ice Shelves. The annual melting 
days and persistent duration in the stable melt area showed a decrease of 0.81 and 0.64 days/year, respectively. Surface snowmelt in Antarctica decreased temporally and spatially from 2002 to 2011.

As a successor of AMSR-E, AMSR2 shares almost the same sensor and orbit parameters with AMSR-E, which can extend this study and discuss the snowmelt trend with a longer observation period. The limited daily satellite observations may result in underestimates of snowmelt. Multi-source remote sensing images, such as scatterometers and SAR images, are expected to enrich the daily observations. An automatic snowmelt detection method based on multi-source satellite data is already in progress. In situ measurements of snow liquid water are valuable and should be collected in the future to validate the Antarctic snowmelt derived by satellites.

Author Contributions: L.Z. and C.Z. conceived the study and conducted the manuscript preparation. L.Z. performed the analysis and prepared the Figures. R.L. and Q.S. contributed to the methodology design and revised the manuscript.

Funding: This research was supported by the National Natural Science Foundation of China (NSFC) (Grant No. 41376187, 41531069 and 41776200).

Acknowledgments: The authors would like to thank the National Climatic Data Center (NCDC) and Chinese National Arctic and Antarctic Data Center (CN-NADC) for providing meteorological data. AMSR-E brightness temperature data was obtained from the National Snow and Ice Data Center (NSIDC). The reviewers and editors are thanked for their helpful and insightful comments.

Conflicts of Interest: The authors declare no conflict of interest.

\section{References}

1. The IMBIE Team. Mass balance of the Antarctic Ice Sheet from 1992 to 2017. Nature 2018, 558, $219-222$. [CrossRef] [PubMed]

2. Turner, J.; Colwell, S.R.; Marshall, G.J.; Lachlan-Cope, T.A.; Carleton, A.M.; Jones, P.D.; Lagun, V.; Reid, P.A.; Iagovkina, S. Antarctic climate change during the last 50 years. Int. J. Climatol. 2005, 25, 279-294. [CrossRef]

3. Depoorter, M.A.; Bamber, J.L.; Griggs, J.A.; Lenaerts, J.T.M.; Ligtenberg, S.R.M.; van den Broeke, M.R.; Moholdt, G. Calving fluxes and basal melt rates of Antarctic ice shelves. Nature 2013, 502, 89-98. [CrossRef] [PubMed]

4. Liu, Y.; Moore, J.C.; Cheng, X.; Gladstone, R.M.; Bassis, J.N.; Liu, H.; Wen, J.; Hui, F. Ocean-driven thinning enhances iceberg calving and retreat of Antarctic ice shelves. Proc. Natl. Acad. Sci. USA 2015, 112, 3263-3268. [CrossRef] [PubMed]

5. Picard, G.; Fily, M.; Gallee, H. Surface melting derived from microwave radiometers: A climatic indicator in Antarctica. Ann. Glaciol. 2007, 46, 29-34. [CrossRef]

6. Picard, G.; Fily, M. Surface melting observations in Antarctica by microwave radiometers: Correcting 26-year time series from changes in acquisition hours. Remote Sens. Environ. 2006, 104, 325-336. [CrossRef]

7. Steffen, K. Surface energy exchange at the equilibrium line on the Greenland ice sheet during onset of melt. Ann. Glaciol. 1995, 21, 13-18. [CrossRef]

8. Kuipers Munneke, P.; Picard, G.; van den Broeke, M.R.; Lenaerts, J.T.M.; van Meijgaard, E. Insignificant change in Antarctic snowmelt volume since 1979. Geophys. Res. Lett. 2012, 39, L01501. [CrossRef]

9. Scambos, T.; Hulbe, C.; Fahnestock, M.; Bohlander, J. The link between climate warning and break-up of ice shelves in the Antarctic Peninsula. J. Glaciol. 2000, 46, 516-530. [CrossRef]

10. Van den Broeke, M. Strong surface melting preceded collapse of Antarctic Peninsula ice shelf. Geophys. Res. Lett. 2005, 32, L12815. [CrossRef]

11. Abdalati, W.; Steffen, K. Greenland Ice Sheet melt extent: 1979-1999. J. Geophys. Res. Atmos. 2001, 106, 33983-33988. [CrossRef]

12. Luckman, A.; Elvidge, A.; Jansen, D.; Kulessa, B.; Kuipers Munneke, P.; King, J.; Barrand, N.E. Surface melt and ponding on Larsen C Ice Shelf and the impact of föhn winds. Antarct. Sci. 2014, 26, 625-635. [CrossRef]

13. Trusel, L.D.; Frey, K.E.; Das, S.B. Antarctic surface melting dynamics: Enhanced perspectives from radar scatterometer data. J. Geophys. Res. Atmos. 2012, 117, F02023. [CrossRef] 
14. Edgerton, A.T.; Ruskey, F.; Williams, D.; Stogryn, A.; Poe, G. Microwave Emission Characteristics of Natural Materials and the Environment (A Summary of Six Years Research); Aerojet General Corporation, EI Monte: Rancho Cordova, CA, USA, 1971.

15. Liu, H.; Wang, L.; Jezek, K.C. Spatiotemporal variations of snowmelt in Antarctica derived from satellite scanning multichannel microwave radiometer and Special Sensor Microwave Imager data (1978-2004). J. Geophys. Res. 2006, 111, F01003. [CrossRef]

16. Yan, B.; Weng, F.; Meng, H. Retrieval of snow surface microwave emissivity from the advanced microwave sounding unit. J. Geophys. Res. 2008, 113, D19206. [CrossRef]

17. Ashcraft, I.S.; Long, D.G. Comparison of methods for melt detection over Greenland using active and passive microwave measurements. Int. J. Remote Sens. 2006, 27, 2469-2488. [CrossRef]

18. Ridley, J. Surface melting on Antarctic Peninsula ice shelves detected by passive microwave sensors. Geophys. Res. Lett. 1993, 20, 2639-2642. [CrossRef]

19. Zwally, H.J.; Fiegles, S. Extent and duration of Antarctic surface melting. J. Glaciol. 1994, 40, 463-475. [CrossRef]

20. Mote, T.L.; Anderson, M.R. Variations in snowpack melt on the Greenland ice sheet based on passive-microwave measurements. J. Glaciol. 1995, 41, 51-60. [CrossRef]

21. Wang, X.D.; Li, X.W.; Liang, L. Spatio-temporal analysis of Antarctic ice-sheet freeze-thaw variation. China Environ. Sci. 2014, 34, 1303-1309.

22. Steffen, K.; Abdalati, W.; Stroeve, J. Climate sensitivity studies of the Greenland ice sheet using satellite AVHRR, SMMR, SSM/I and in situ data. Meteorol. Atmos. Phys. 1993, 51, 239-258. [CrossRef]

23. Abdalati, W.; Steffen, K. Passive microwave-derived snow melt regions on the Greenland Ice Sheet. Geophys. Res. Lett. 1995, 22, 787-790. [CrossRef]

24. Abdalati, W.; Steffen, K. Snowmelt on the Greenland Ice Sheet as derived from passive microwave satellite data. J. Clim. 1997, 10, 165-175. [CrossRef]

25. Fahnestock, M.A.; Abdalati, W.; Shuman, C.A. Long melt seasons on ice shelves of the Antarctic Peninsula: An analysis using satellite-based microwave emission measurements. Ann. Glaciol. 2001, 34, 127-133. [CrossRef]

26. Steffen, K. The melt anomaly of 2002 on the Greenland Ice Sheet from active and passive microwave satellite observations. Geophys. Res. Lett. 2004, 31, 349-371. [CrossRef]

27. Fettweis, X.; van Ypersele, J.-P.; Gallée, H.; Lefebre, F.; Lefebvre, W. The 1979-2005 Greenland ice sheet melt extent from passive microwave data using an improved version of the melt retrieval XPGR algorithm. Geophys. Res. Lett. 2007, 34, L05502. [CrossRef]

28. Liang, L.; Guo, H.; Li, X.; Cheng, X. Automated ice-sheet snowmelt detection using microwave radiometer measurements. Polar Res. 2013, 32, 1-13. [CrossRef]

29. Joshi, M.; Merry, C.J.; Jezek, K.C.; Bolzan, J.F. An edge detection technique to estimate melt duration, season and melt extent on the Greenland Ice Sheet using Passive Microwave Data. Geophys. Res. Lett. 2001, 28, 3497-3500. [CrossRef]

30. Liu, H.; Wang, L.; Jezek, K.C. Wavelet-transform based edge detection approach to derivation of snowmelt onset, end and duration from satellite passive microwave measurements. Int. J. Remote Sens. 2005, 26, 4639-4660. [CrossRef]

31. Xiong, Z.; Wang, X.; Li, X.; Liang, L. Antarctic Ice-Sheet freeze-thaw detection based on improved physical model. Chin. J. Electron. 2014, 23, 209-212.

32. Markus, T.; Stroeve, J.C.; Miller, J. Recent changes in Arctic sea ice melt onset, freezeup, and melt season length. J. Geophys. Res. Ocean. 2009, 114, C12024. [CrossRef]

33. Hall, D.K.; Nghiem, S.V.; Schaaf, C.B.; DiGirolamo, N.E.; Neumann, G. Evaluation of surface and near-surface melt characteristics on the Greenland ice sheet using MODIS and QuikSCAT data. J. Geophys. Res. Earth Surf. 2009, 114, F04006. [CrossRef]

34. Van den Broeke, M.; Bus, C.; Ettema, J.; Smeets, P. Temperature thresholds for degree-day modelling of Greenland ice sheet melt rates. Geophys. Res. Lett. 2010, 37, L18501. [CrossRef]

35. Ramage, J.M.; Isacks, B.L. Determination of melt-onset and refreeze timing on southeast Alaskan icefields using SSM/I diurnal amplitude variations. Ann. Glaciol. 2002, 34, 391-398. [CrossRef]

36. Ramage, J.M.; Isacks, B.L. Interannual variations of snowmelt and refreeze timing on southeast-Alaskan icefields, U.S.A. J. Glaciol. 2003, 49, 102-116. [CrossRef] 
37. Tedesco, M. Snowmelt detection over the Greenland ice sheet from SSM/I brightness temperature daily variations. Geophys. Res. Lett. 2007, 34, L02504. [CrossRef]

38. Knowles, M.; Armstrong, R.; Brodzik, M.J. AMSR-E/Aqua Daily EASE-Grid Brightness Temperatures, Version 1. Boulder, Colorado, USA. Available online: http://nsidc.org/data/nsidc-0301 (accessed on 5 September 2015).

39. Bohlander, J.; Scambos, T. Antarctic Coastlines And Grounding Line Derived from MODIS Mosaic of Antarctica (MOA), Boulder, Colorado, USA: National Snow and Ice Data Center. Available online: http: //nsidc.org/data/atlas/news/antarctic_coastlines.html (accessed on 5 September 2015).

40. Bamber, J.L.; Gomez-Dans, J.L.; Griggs, J.A. A new $1 \mathrm{~km}$ digital elevation model of the Antarctic derived from combined satellite radar and laser data-Part 1: Data and methods. Cryosphere 2008, 3, 101-111. [CrossRef]

41. Griggs, J.A.; Bamber, J.L. A new $1 \mathrm{~km}$ digital elevation model of Antarctica derived from combined radar and laser data-Part 2: Validation and error estimates. Cryosphere 2009, 3, 113-123. [CrossRef]

42. Lazzara, M.A.; Weidner, G.A.; Keller, L.M.; Thom, J.E.; Cassano, J.J. Antarctic automatic weather station program: 30 years of polar observations. Bull. Am. Meteorol. Soc. 2012, 93, 1519-1537. [CrossRef]

43. Wiesmann, A.; Mätzler, C. Microwave emission model of layered snowpacks. Remote Sens. Environ. 1999, 70, 307-316. [CrossRef]

44. Rees, A.; Lemmetyinen, J.; Derksen, C.; Pulliainen, J.; English, M. Observed and modelled effects of ice lens formation on passive microwave brightness temperatures over snow covered tundra. Remote Sens. Environ. 2010, 114, 116-126. [CrossRef]

45. Semmens, K.A.; Ramage, J.; Bartsch, A.; Liston, G.E. Early snowmelt events: Detection, distribution, and significance in a major sub-arctic watershed. Environ. Res. Lett. 2013, 8, 014020. [CrossRef]

46. Foster, J.L.; Hall, D.K.; Eylander, J.B.; Riggs, G.A.; Nghiem, S.V.; Tedesco, M.; Kim, E.; Montesano, P.M.; Kelly, R.E.J.; et al. A blended global snow product using visible, passive microwave and scatterometer satellite data. Int. J. Remote Sens. 2011, 32, 1371-1395. [CrossRef]

47. Grody, N.; Weng, F.; Ferraro, R. Application of AMSU for obtaining water vapor, cloud liquid water, precipitation, snow cover, and sea ice concentration. In Proceedings of the Tenth Technical International TOVS Study Conference, Boulder, CO, USA, 27 January-2 February 1999; pp. 230-240.

48. Spreen, G.; Kaleschke, L.; Heygster, G. Sea ice remote sensing using AMSR-E 89-GHz channels. J. Geophys. Res. Ocean. 2008, 113, C02S03. [CrossRef]

49. Apgar, J.D.; Ramage, J.M.; Rose, A.M.; Patrick, M. AMSR-E algorithm for snowmelt onset detection in sub-arctic heterogeneous terrain. Hydrol. Process. 2007, 21, 1587-1596. [CrossRef]

50. Ramage, J.M.; Apgar, J.D.; McKenney, R.A.; Hanna, W. Spatial variability of snowmelt timing from AMSR-E and SSM/I passive microwave sensors, Pelly River, Yukon Territory, Canada. Hydrol. Process. 2007, 21, 1548-1560. [CrossRef]

51. Monahan, P.A.; Ramage, J. AMSR-E melt patterns on the Southern Patagonia Icefield. J. Glaciol. 2010, 56, 699-708. [CrossRef]

52. Mätzler, C.; Wiesmann, A. Extension of the microwave emission model of layered snowpacks to coarse-grained snow. Remote Sens. Environ. 1999, 70, 317-325. [CrossRef]

53. Tedesco, M.; Kim, E.J. Intercomparison of electromagnetic models for passive microwave remote sensing of snow. IEEE Trans. Geosci. Remote Sens. 2006, 44, 2654-2666. [CrossRef]

54. Tedesco, M. Assessment and development of snowmelt retrieval algorithms over Antarctica from K-band spaceborne brightness temperature (1979-2008). Remote Sens. Environ. 2009, 113, 979-997. [CrossRef]

55. Qin, D.H.; Ren, J.W. A study on snow profiles and surface characteristics along $6000 \mathrm{~km}$ trans-Antarctic route 1 the 1990 international trans-Antarctic expedition glaciological research. Sci. China Chem. 1992, 35, 366-374.

56. Judson, A.; Doesken, N. Density of Freshly Fallen Snow in the Central Rocky Mountains. Bull. Am. Meteorol. Soc. 2000, 81, 1577-1587. [CrossRef]

57. Ding, M.; Xiao, C.; Li, Y.; Ren, J.; Hou, S.; Jin, B.; Sun, B. Spatial variability of surface mass balance along a traverse route from Zhongshan station to Dome A, Antarctica. J. Glaciol. 2011, 57, 658-666.

58. Davis, R.E.; Dozier, J. Stereological characterization of dry alpine snow for microwave remote sensing. Adv. Space Res. 1989, 9, 245-251. [CrossRef]

59. Mätzler, C. Relation between grain-size and correlation length of snow. J. Glaciol. 2002, 48, 461-466. [CrossRef]

60. Japan Aerospace Exploration Agency. AMSR-E Data Users Handbook; JAXA Earth Observation Center: Saitama, Japan, 2006. 
61. Powell, D.C.; Markus, T.; Cavalieri, D.J.; Gasiewski, A.J. Microwave Signatures of Snow on Sea Ice: Modeling. IEEE Trans. Geosci. Remote Sens. 2006, 44, 3091-3102. [CrossRef]

62. Dai, L.; Tao, C.; Jian, W.; Pu, Z. Snow depth and snow water equivalent estimation from AMSR-E data based on a priori snow characteristics in Xinjiang, China. Remote Sens. Environ. 2012, 127, 14-29. [CrossRef]

63. Hallikainen, M.T.; Ulaby, F.; Abdelrazik, M. Dielectric properties of snow in the 3 to $37 \mathrm{GHz}$ range. IEEE Trans. Antennas Propag. 1986, 34, 1329-1340. [CrossRef]

64. Willmes, S.; Haas, C.; Nicolaus, M.; Bareiss, J. Satellite microwave observations of the interannual variability of snowmelt on sea ice in the Southern Ocean. J. Geophys. Res. 2009, 114, C03006. [CrossRef]

65. Xiao, C.; Li, Y.; Ian, A.; Hou, S.; Gabrielle, D.; Jean Marc, B.; Ren, J.; Bian, L.; Zhang, S.; Kameda, T. Surface characteristics at Dome A, Antarctica: First measurements and a guide to future ice-coring sites. Ann. Glaciol. 2008, 48, 82-87.

66. Tedesco, M.; Abdalati, W.; Zwally, H.J. Persistent surface snowmelt over Antarctica (1987-2006) from 19.35 GHz brightness temperatures. Geophys. Res. Lett. 2007, 34, L18594. [CrossRef]

67. Hock, R.; Braun, M. Lapse rates and their effect on melt modelling of King George Island (Antarctica). In AGU Spring Meeting Abstracts; American Geophysical Union: Monteal, QC, Canada, 2004.

68. Van den Broeke, M.; König-Langlo, G.; Picard, G.; Kuipers Munneke, P.; Lenaerts, J. Surface energy balance, melt and sublimation at Neumayer Station, East Antarctica. Antarct. Sci. 2010, 22, 87-96. [CrossRef]

69. Willmes, S.; Bareiss, J.; Haas, C.; Nicolaus, M. The importance of diurnal processes for the Seasonal cycle of Sea-ice microwave brightness temperatures during early Summer in the Weddell Sea, Antarctica. Ann. Glaciol. 2006, 44, 297-302. [CrossRef]

70. Brucker, L.; Picard, G.; Fily, M. Snow grain-size profiles deduced from microwave snow emissivities in Antarctica. J. Glaciol. 2010, 56, 514-526. [CrossRef]

71. Herron, M.M.; Langway, C.C. Firn densification: An empirical model. J. Glaciol. 1980, 25, 373-385. [CrossRef]

72. Hui, F.; Ci, T.; Cheng, X.; Scambos, T.A.; Liu, Y.; Zhang, Y.; Chi, Z.; Huang, H.; Wang, X.; Wang, F.; et al. Mapping blue-ice areas in Antarctica using ETM+ and MODIS data. Ann. Glaciol. 2014, 55, 129-137. [CrossRef]

73. Kingslake, J.; Ely, J.C.; Das, I.; Bell, R.E. Widespread movement of meltwater onto and across Antarctic ice shelves. Nature 2017, 544, 349-352. [CrossRef] [PubMed]

74. Eppler, D.T.; Farmer, L.D.; Lohanick, A.W.; Anderson, M.R.; Cavalieri, D.J.; Comiso, J.; Gloersen, P.; Garrity, C.; Grenfell, T.C.; Hallikainen, M.; et al. Passive Microwave Signatures of Sea Ice; American Geophysical Union: Washington, DC, USA, 1992; p. 55.

75. Wentz, F.J.; Meissner, T. Supplement 1 Algorithm Theoretical Basis Document for AMSR-E Ocean Algorithms; NASA: Santa Rosa, CA, USA, 2007.

76. Steiner, N.; Tedesco, M. A wavelet melt detection algorithm applied to enhanced-resolution scatterometer data over Antarctica (2000-2009). Cryosphere 2014, 8, 25-40. [CrossRef]

77. Bothale, R.V.; Rao, P.V.N.; Dutt, C.B.S.; Dadhwal, V.K.; Maurya, D. Spatio-temporal dynamics of surface melting over Antarctica using OSCAT and QuikSCAT scatterometer data (2001-2014). Curr. Sci. 2015, 109, 733-744.

78. Zhou, C.; Zheng, L. Mapping Radar Glacier Zones and Dry Snow Line in the Antarctic Peninsula Using Sentinel-1 Images. Remote Sens. 2017, 9, 1171. [CrossRef]

79. Tedesco, M.; Monaghan, A.J. An updated Antarctic melt record through 2009 and its linkages to high-latitude and tropical climate variability. Geophys. Res. Lett. 2009, 36, L18502. [CrossRef]

80. Monaghan, A.J.; Bromwich, D.H.; Chapman, W.; Comiso, J.C. Recent variability and trends of Antarctic near-surface temperature. J. Geophys. Res. Atmos. 2008, 113, D04105. [CrossRef]

81. Clem, K.R.; Fogt, R.L. South Pacific circulation changes and their connection to the tropics and regional Antarctic warming in austral spring, 1979-2012. J. Geophys. Res. Atmos. 2015, 120, 2773-2792. [CrossRef]

82. Fettweis, X.; Gallée, H.; Lefebre, F.; van Ypersele, J.P. Greenland surface mass balance simulated by a regional climate model and comparison with satellite-derived data in 1990-1991. Clim. Dyn. 2005, 24, 623-640. [CrossRef]

83. Rignot, E.; Casassa, G.; Gogineni, P.; Krabill, W.; Rivera, A.; Thomas, R. Accelerated ice discharge from the Antarctic Peninsula following the collapse of Larsen B ice shelf. Geophys. Res. Lett. 2004, 31, L18401. [CrossRef] 